\title{
Biostratigraphy and microfacies of the pelagic carbonate formations in the Yavorets section (Tithonian-Berriasian), Western Balkan Mts, Bulgaria
}

\author{
Silviya Petrova, Elena Koleva-Rekalova, Daria Ivanova, Iskra Lakova
}

Geological Institute, Bulgarian Academy of Sciences, Acad. G. Bonchev Str., Bl. 24, 1113 Sofia, Bulgaria; e-mails: silviya_p@geology.bas.bg; e_koleva@geology.bas.bg; dariaiv@yahoo.com; lakova@geology.bas.bg

(Accepted in revised form: August 2019)

\begin{abstract}
Calpionellid study has provided new evidence of early and late Tithonian age of the top of the Gintsi Formation, and of late Tithonian and early Berriasian age of the Glozhene Formation in the Yavorets section (Western Balkan Mts, Bulgaria). The calpionellid Chitinoidella, Praetintinnopsella, Crassicollaria, and Calpionella zones have been documented in successive order. Three calcareous dinocyst zones Colomisphaera tenuis, Colomisphaera fortis and Stomiosphaerina proxima, have been determined in this lower Tithonian to lower Berriasian interval. From the base upwards, the following microfacies have been recognized: Saccocoma (Gintsi Formation, lower and upper Tithonian), Globochaete alpina, and calpionellid (Glozhene Formation, upper Tithonian and lower Berriasian). The base of the Berriasian has been traced at the explosion of the uniformly shaped spherical variety of Calpionella alpina. Evolutionary lineages of species of the genus Calpionella are discussed, as well as the vertical distributions and abundance peaks of crassicollarians. The calpionellid zones described herein are correlated with coeval zonations from the Western, Central and Eastern Tethyan domains. The regional correlation with previously studied sections of Tithonian/ Berriasian pelagic carbonates in the Western Balkan Mts revealed a transition to hemipelagic deposition of the limestone-marl succession of the Salash Formation and/or sandstone accumulation during the middle to late Berriasian (Elliptica and Simplex calpionellid subzones) due to unstable conditions of the sedimentary environment. From the west to the east in the Western Balkan Unit (i.e., from the Rosomač section in eastern Serbia to the Sarbenitsa, Bov and Yavorets sections in the Iskar River Valley area), there is a trend of slight progressive deepening of the basin. This is manifested in the occurrence of redeposited shallow-carbonateplatform microfossils in the west to greater thickenesses of the Gintsi and Glozhene formations and occurrence of sandstone channel deposits in the east.
\end{abstract}

Petrova, S., Koleva-Rekalova, E., Ivanova, D., Lakova, I. 2019. Biostratigraphy and microfacies of the pelagic carbonate formations in the Yavorets section (Tithonian-Berriasian), Western Balkan Mts, Bulgaria. Geologica Balcanica 48 (2), 51-73.

Keywords: calpionellid zones, calcareous dinocyst zones, microfacies, Tithonian, Berriasian, pelagic limestones, Western Balkan Mts, Bulgaria.

\section{INTRODUCTION}

The outcrops of the Yavorets, Gintsi and Glozhene formations around Yavorets Peak in the Yavorets syncline represent the easternmost ones in the West Balkan Mts (Fig. 1). To the west, the sections of Gintsi, Komshtitsa, Barlya, and the one in Rosomač in eastern Serbia have remained better studied for decades in terms of ammonite, calpionellid and calcareous dinocyst biostratigraphy, and carbonate microfacies. The biostratigraphic and microfacies results yielded in this study are continuation of previous researches.

The purpose of this study is to erect calpionellid and calcareous dinocyst biostratigraphy and recognize microfacies of the top of the Gintsi Formation and the Glozhene Formarion, and to correlate the results with the westerly-located sections at Gintsi and Barlya. The whole section of pelagic limestones on the western slope of Yavorets Peak reveals a 

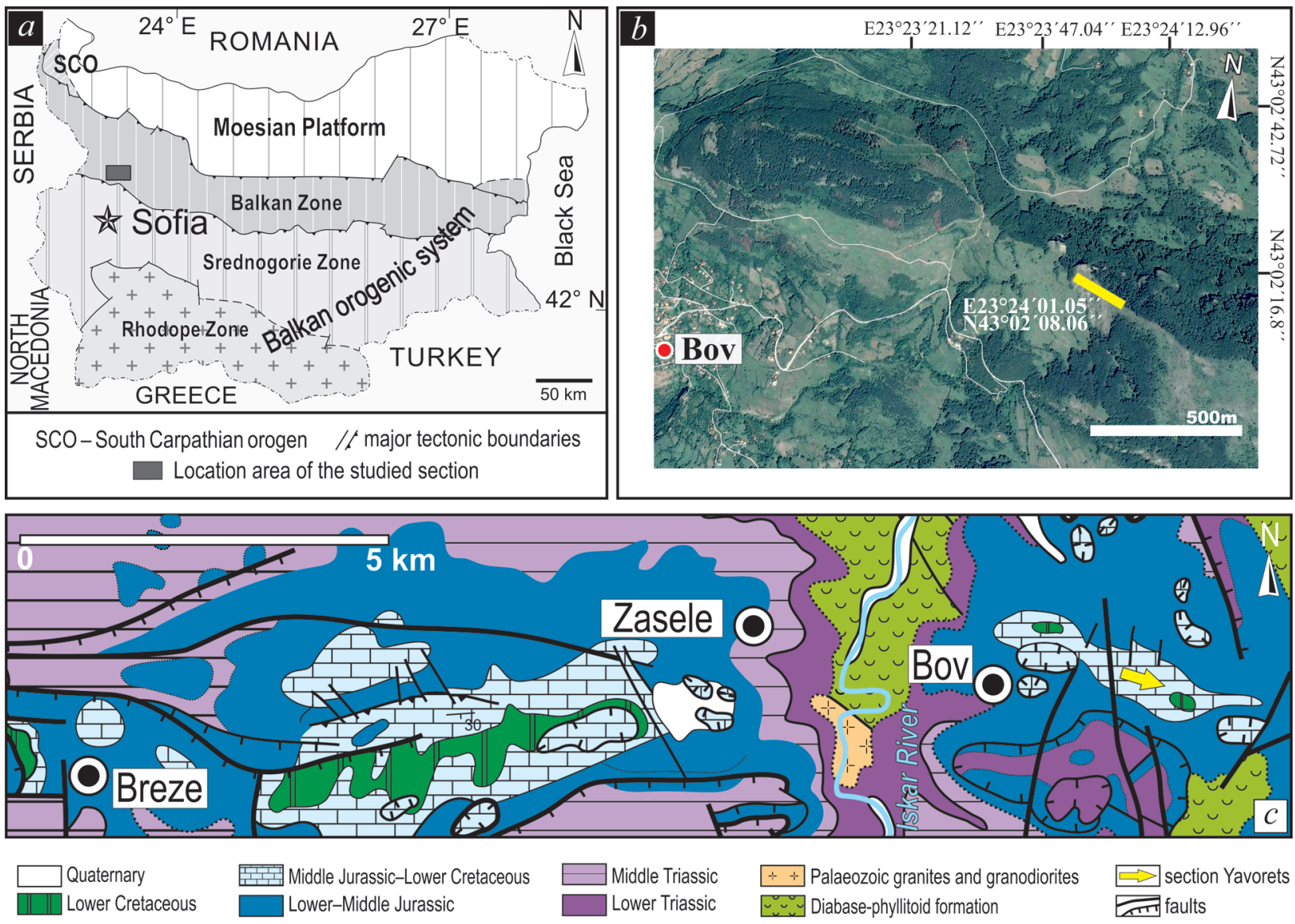

$\Longrightarrow$ section Yavorets

Fig. 1. Location of the studied section: a) Tectonic subdivision of Bulgaria (after Dabovski and Zagorchev, 2009; modified); b) Geographic position of the section (the map is a satellite image taken from Google Earth); c) Geological map of the studied area and position of the section (after Angelov et al., 1992; simplified).

continuous succession of the Yavorets, Gintsi, Glozhene and Salash formations and covers the time interval from the Callovian-Oxfordian to the late Berriasian. Its detailed description, calpionellid and calcareous dinocyst biostratigraphy, carbonate microfacies, and extensive illustration will be a subject of another publication.

\section{LITHOSTRATIGRAPHY AND PREVIOUS STUDIES}

Nikolov and Sapunov (1970) introduced three formations of pelagic limestones, which are largely represented in the Western Balkan Mts, namely the Yavorets, Gintsi, and Glozhene formations in ascending stratigraphic order. All three are included in the Western Balkan Carbonate Group. These formations build up the western slope of Yavorets Peak, which is the location of this study. Sapunov (1976) described this section, mention- ing its lithologic features, the ammonite finds, and thicknesses.

\section{Gintsi Formation}

Sapunov (1977a, b) recognized the Hybonoticeras beckeri (uppermost Kimmeridgian) and Hybonoticeras hybonotum (lowermost Tithonian) ammonite zones in the Gintsi Formation, in the uppermost packages 6 and 7, respectively, beneath Yavorets Peak. These levels occur below the strata with the first chitinoidellids, which are described herein.

From a section at Bov Village, situated $\sim 2 \mathrm{~km}$ to the west of the studied profile at Yavorets Peak, Metodiev and Sapunov (2008) reported new ammonite finds in the Gintsi Formation. Thus, the chronostratigraphic extent of this formation in the area has previously been documented as ranging from the lower Kimmeridgian [Ataxioceras (Parataxioceras) desmoides Zone] to the lower Tithonian [Hybonoticeras hybonotum Zone]. 


\section{Glozhene Formation}

Mandov (1972) cited earlier finds of the brachiopod Pygope janitor (Pictet, 1868) and of the calpionellid species Calpionella alpina Lorenz, 1902 and Calpionella elliptica Cadisch, 1932 from the sediments of Glozhene Formation in the Yavorets syncline. He also placed the Jurassic/Cretaceous boundary at the top of the formation. Petrova (2010) revised these data and referred the upper part of the formation to the upper Berriasian, i.e., Jurassic/Cretaceous boundary passes down-section in the Glozhene Formation.

\section{MATERIAL AND METHOD}

A total of 30 samples were collected throughout the 77.5-m thick interval of the Yavorets section. Sampling density depends on exposure, the average intervals being from $2 \mathrm{~m}$ (samples Ya 23-Ya 32) to 1.5-5 m (samples Ya 33-Ya 52). The taxonomic identification of calpionellids and calcareous dinocysts was performed in the Geological Institute, Sofia, using Jenaval (for calpionellids) and Amplival (for calcareous dinoflagellate cysts) transmitting light-microscopes. The limestones were classified, using the textural scheme of Dunham (1962). Microfacies were determined based on the predominant microfossil content, in accordance with the paleontological microfacies of Reháková et al. (2011). In addition, one of the microfacies is correlated with the Standard Microfacies Types (SMF) of Flügel (2004). Thin-sections are hosted in the Department of Paleontology, Stratigraphy and Sedimentology of the Geological Institute "Str. Dimitrov" (Sofia, Bulgaria).

\section{DESCRIPTION OF THE YAVORETS SECTION}

The Yavorets section is located to the east of the right bank of the Iskar River, east of the village of Bov (Sofia District), on the western slope of Yavorets Peak (Fig. 1b; 4302'08.29" N; 2324'01.05" E). The section covers a part of the pelagic carbonates of the Yavorets syncline (Western Balkan Mts) (Fig. 1 $a-c$ ). Sampling for the micropaleontological and microfacies studies follows the descriptions of the Yavorets, Gintsi and Glozhene formations of Sapunov (1976). Our investigation covers the topmost package of the Gintsi Formation and the whole Glozhene Formation. The section is herein described from the base upwards.

The Gintsi Formation (11 m thick) is represented by an alternation of light gray to pale rose-colored thin-bedded or medium-bedded intraclastic limestones with medium-bedded nodular limestones and single layers of light gray thin-bedded micritic limestones (Fig. 2a, $b$ ).

The overlying Glozhene Formation (66.5 m thick) is characterized by an alternation of gray thinto medium-bedded intraclastic limestones with gray medium-bedded nodular limestones in the lower part (Fig. 2c, d) and an alternation of dark gray thinto medium-bedded mictitic limestones with gray thin- to medium-bedded clayey limestones in the upper part (Fig. 2e, f).

\section{CALPIONELLID BIOSTRATIGRAPHY}

A continuous succession of the calpionellid Chitinoidella, Praetintinnopsella, Crassicollaria zones and the lower part of the Calpionella Zone is herein described (Fig. 3). The definitions of the chitinoidellid and calpionellid zones and subzones follow those of Remane et al. (1986), Reháková (1995), Reháková and Michalík (1997), Pop (1994b, 1997b), and Lakova and Petrova (2013).

A thorough review of interregional correlation of these zones and their subzones can be found in the work of Lakova and Petrova (2013). Only recently published zonations in Tunisia, Slovakia, Argentina, and elsewhere are included in this paper for correlation purpose (e.g., Boughdiri et al., 2009; Michalík et al., 2016; Kietzmann, 2017).

\section{Chitinoidella Zone}

The zone is defined at the first occurrence (FO) of microgranular-walled chitinoidellids. It became evident that chitinoidellids are absent from most of the Gintsi Formation and that they have their FO in sample Ya 24 in the upper package of the Gintsi Formation.

Chitinoidellids in the Yavorets section are remarkably diverse in species as those from the South Carpathians in Romania (Pop, 1997a, 1998a, b), Tunisia (Boughdiri et al., 2009; Sallouhi et al., 2011), and Morocco (Benzaggagh et al., 2010).

Chitinoidellids have been largely observed in the topmost package of the Gintsi Formation and at the base of the Glozhene Formation. The abundance is as great as at the Gintsi and Barlya sections (see Lakova and Petrova, 2013) and is much greater than in coeval Tithonian strata of the Western Carpathians in Slovakia (D. Reháková, pers. comm.). A total of 21 chitinoidellid species have been identified (Figs 3-5). The Chitinoidella Zone was divided into the Longicollaria dobeni and Chitinoidella boneti subzones (Fig. 3), the 

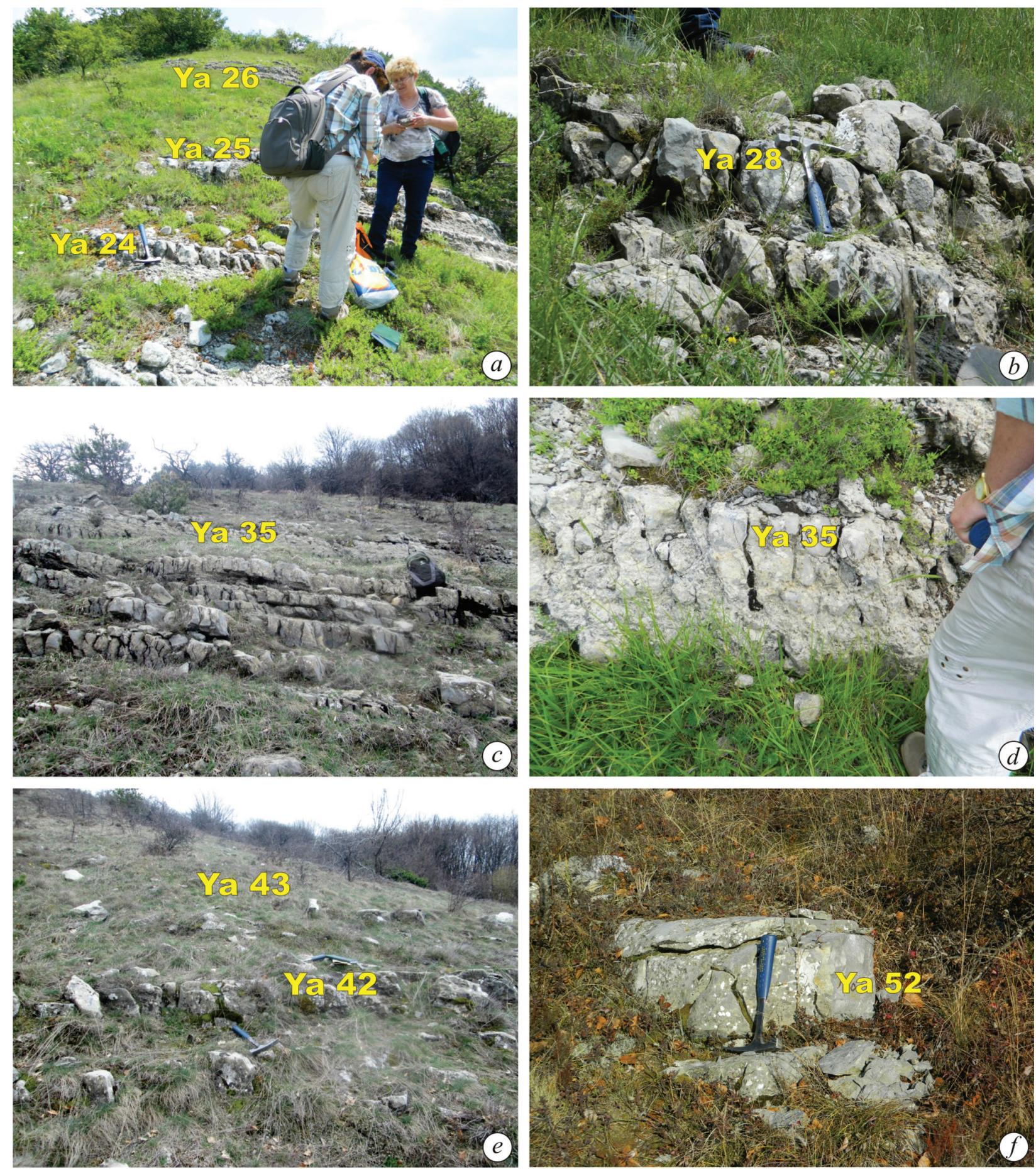

Fig. 2. Views from the Yavorets section with sample numbers: a) Alternation of light gray thin-bedded intraclastic limestones with medium-bedded nodular limestones and single layers of light gray thin-bedded micritic limestones of the Gintsi Fm. (lower Tithonian); b) Gray medium-bedded intraclastic limestones of the Gintsi Fm. (upper Tithonian); c) Alternation of gray thinto medium-bedded intraclastic limestones with gray medium-bedded nodular limestones from the lower part of the Glozhene Fm. (upper Tithonian); d) Medium-bedded gray nodular limestones from the lower part of the Glozhene Fm. (upper Tithonian); e) Alternation of dark gray thin- to medium-bedded micritic limestones with gray thin- to medium-bedded clayey limestones of the Glozhene Fm. (lower Berriasian); f) Medium-bedded gray micritic limestones from the top of the Glozhene Fm. (lower Berriasian).

base of the Boneti Subzone being accepted as the base of the upper Tithonian (see Benzaggagh et al., 2010). Many chitinoidellid species also occur upwards in the Praetintinnopsella Zone and in the Remanei Subzone of the Crassicollaria Zone (Fig. 3). 


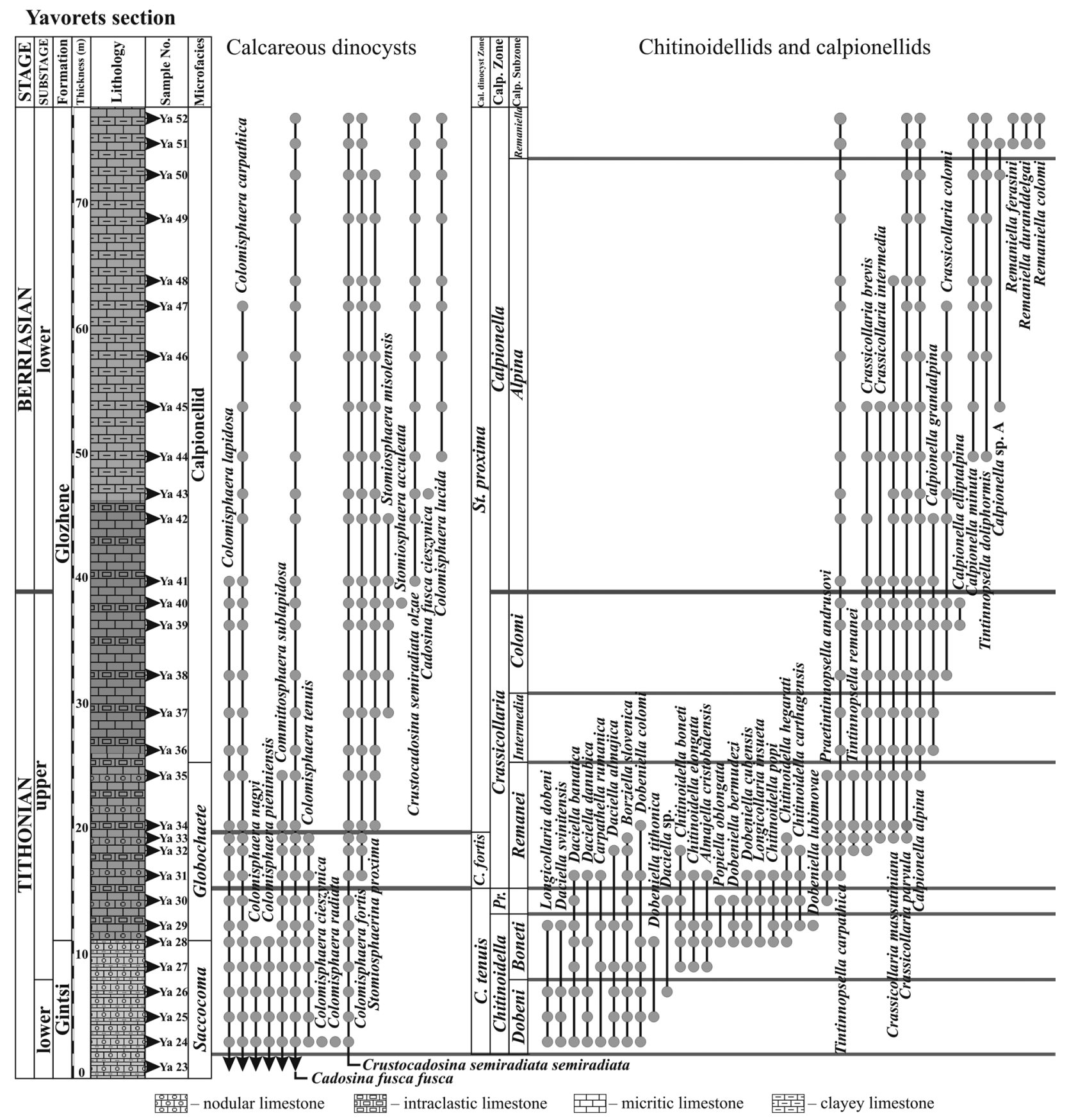

Fig. 3. Yavorets section: litho- and biostratigraphy, range-chart of the calcareous dinocyst, chitinoidellid and calpionellid species, microfacies types.

\section{Longicollaria dobeni Subzone}

This subzone occurs in the topmost package 3 (sensu Sapunov, 1976, 1977b) of the Gintsi Formation above the level with Hybonoticeras hybonotum found at the very base of this package. The chitinoidellid species identified, apart from the subzonal index Longicollaria dobeni, also include Daciella svinitensis, Daciella danubica, Daciella banatica, Daciella almajica, Carpathella rumanica, Borziella slovenica, Dobeniella colomi, Dobeniella tithonica, and Dobeniella sp. (Figs 3, 4). The Dobeni Subzone was documented in samples Ya 24, Ya 25, and Ya 26. Its thickness is $\sim 6 \mathrm{~m}$. Down-section, no chitinoidellids were observed. This subzone correlates well with the homonymous subzone in the Western Carpathians in Slovakia (Reháková, 1995), South Carpathians in Romania (Pop, 1997b), and Tunisia (Boughdiri et al., 2009). 

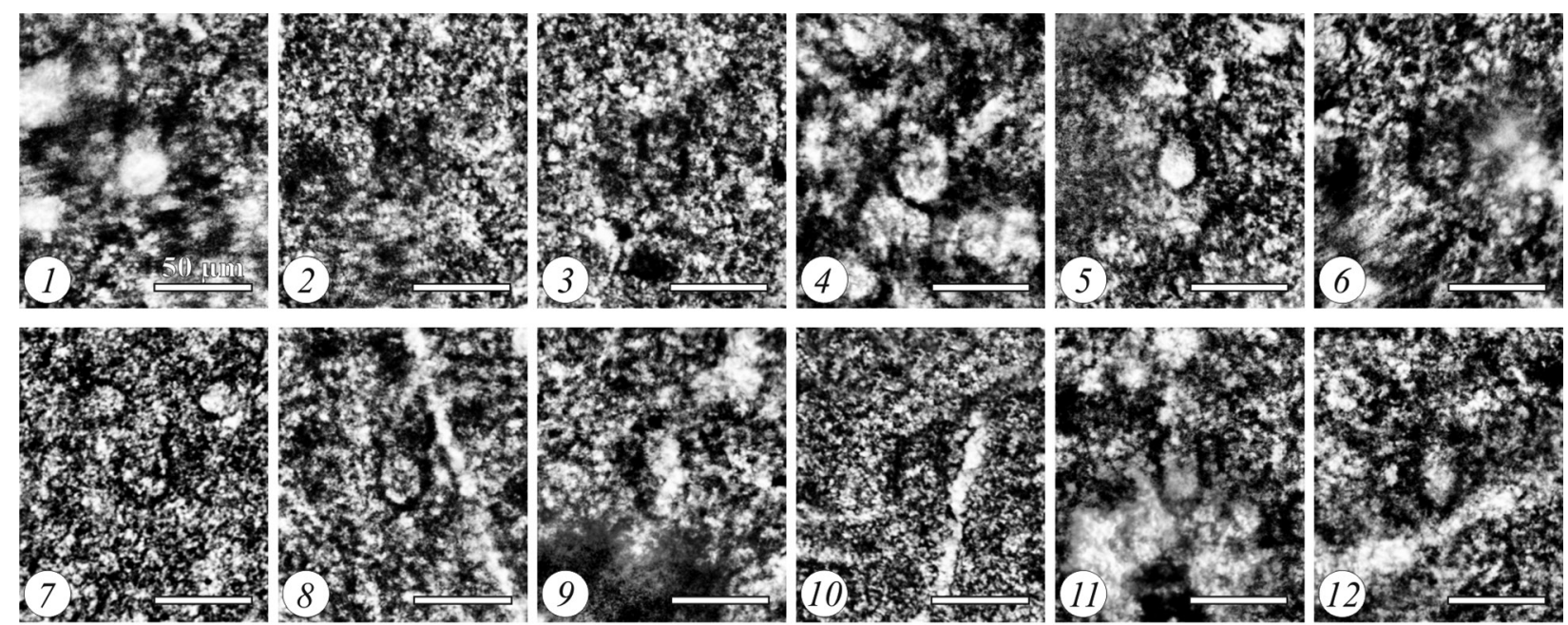

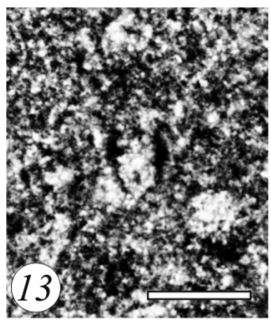
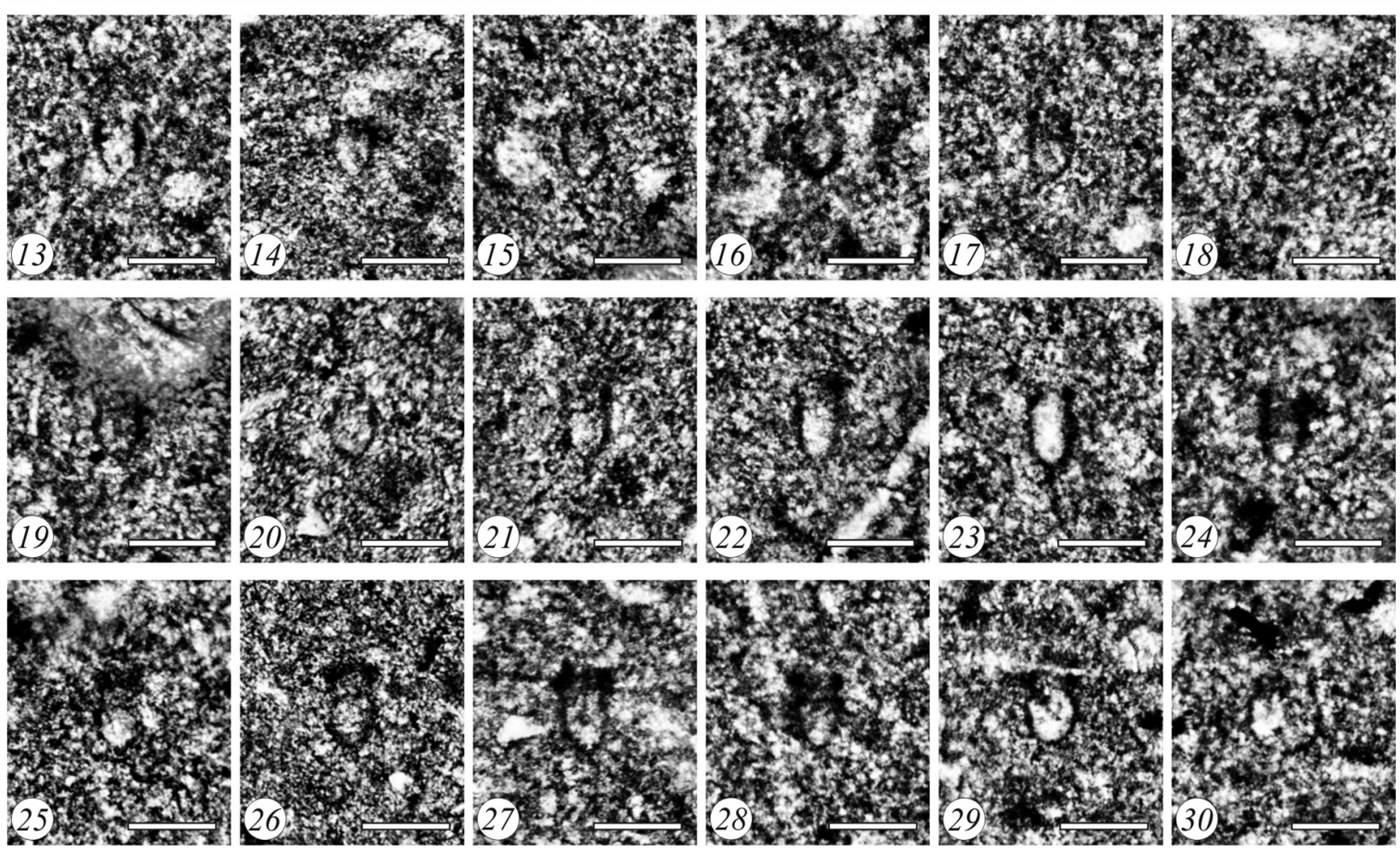

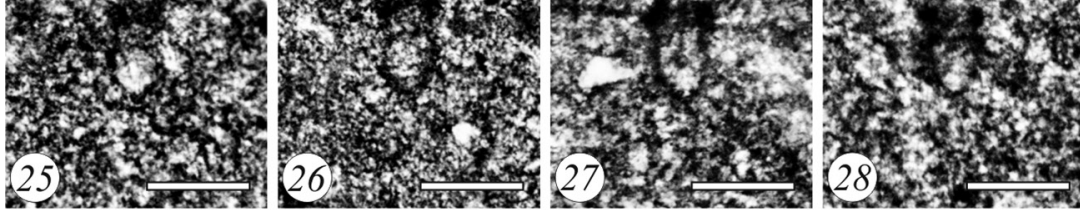
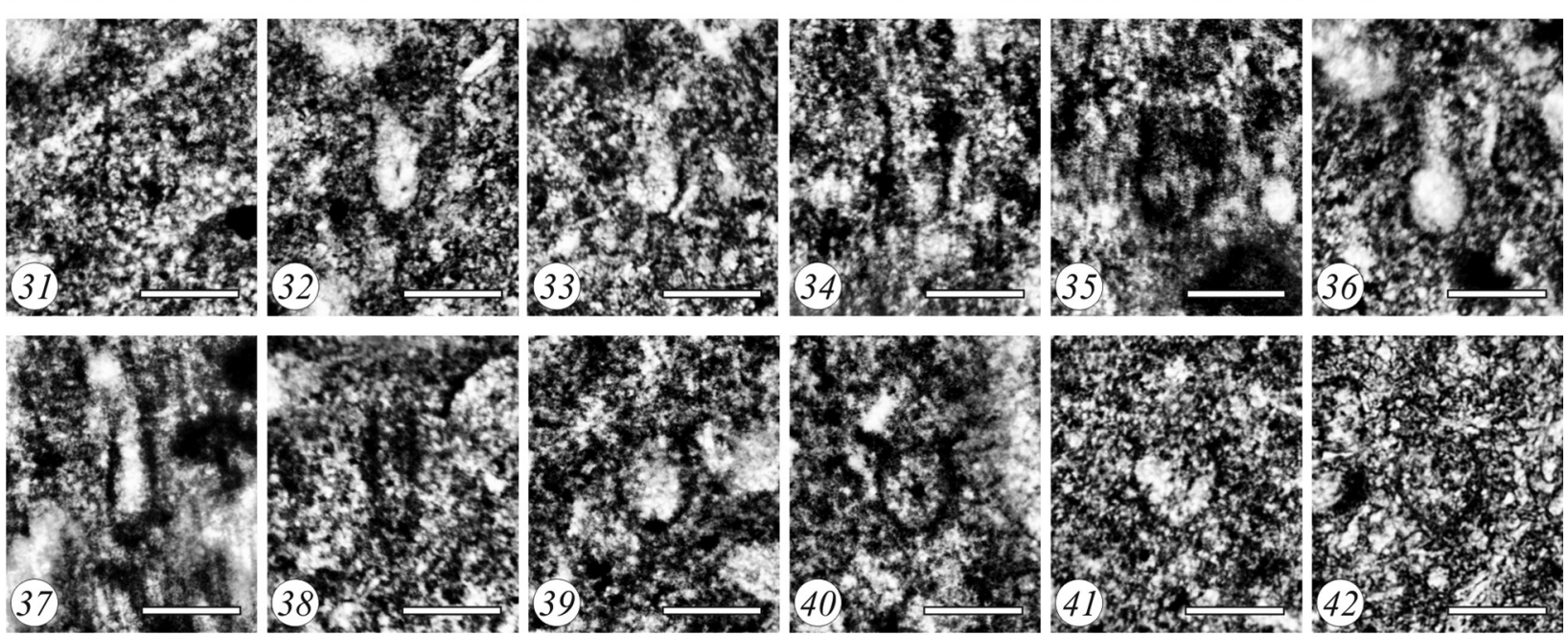
Fig. 4. Chitinoidellids from the Yavorets section: 1-4) Longicollaria dobeni, sample Ya 25 (1-2), sample Ya 24 (3), sample Ya 26 (4); 5-8) Borziella slovenica, sample Ya 24 (5, 8), sample Ya 25 (6, 7); 9-12) Daciella almajica, sample Ya 26 (9), sample Ya 24 (10-12); 13-16) Daciella banatica, sample Ya 24; 17-20) Daciella danubica, sample Ya 24; 21-24) Daciella svinitensis, sample Ya 24; 25-28) Dobeniella colomi, sample Ya 25 (25), sample Ya 24 (26-28); 29) Dobeniella tithonica, sample Ya 25; 30) Carpathella rumanica, sample Ya 29; 31-33) Daciella sp., sample Ya 26 (31), sample Ya 30 (32-33); 34-36) Longicollaria insueta, sample Ya 28 (34, 35), sample Ya 31 (36); 37-38) Popiella oblongata, sample Ya 28 (37), sample Ya 30 (38); 39-42) Chitinoidella boneti, sample Ya 29 (39-41), sample Ya 31 (42). The scale bar is $50 \mu \mathrm{m}$.

\section{Chitinoidella boneti Subzone}

This subzone occupies the uppermost part of the Gintsi Formation and a transitional package of gray nodular and intraclastic limestones between the typical Gintsi and Glozhene formations (samples Ya 27, Ya 28, and Ya 29) and its thickness could be assessed to about $6 \mathrm{~m}$. The index-species Chitinoidella boneti co-occurs with Chitinoidella elongata, Almajella cristobalensis, Dobeniella bermudezi, Dobeniella cubensis, Popiella oblongata, Longicollaria insueta, Chitinoidella popi, Chitinoidella hegarati, Chitinoidella carthagensis, and Dobeniella lubimovae (Figs 3, 5). Besides, all species from the Dobeni Subzone continue ranging in the Boneti Subzone, too. This diverse association suggests a reliable correlation with the Boneti Subzone from Slovakia, Romania and Tunisia.

\section{Praetintinnopsella Zone}

The Praetintinnopsella Zone normally coincides with the fast transition between the Gintsi and Glozhene formations, which is lithologically manifested in predominance of micritic and intraclastic limestones and rapid decrease and disappearing of clayey nodular limestones (Lakova et al., 2007; Lakova and Petrova, 2013). In the Yavorets section, the zone occupies the base of the Glozhene Formation (sample Ya 30) (Fig. 3). Its thickness is about $1.5-2 \mathrm{~m}$. The base is defined at the first occurrence of the index-species Praetintinnopsella andrusovi, which is very abundant. Other species, ranging up from the Boneti Subzone, are Chitinoidella boneti, Dobeniella cubensis, Dobeniella bermudezi, Popiella oblongata, Longicollaria insueta, Chitinoidella popi, Chitinoidella hegarati, and Chitinoidella carthagensis. There are also rare representatives of the Dobeni Subzone, e.g., Daciella banatica, Borziella slovenica, and Daciella sp. (Figs 4, 5).

\section{Crassicollaria Zone}

In the Western Balkan Mts, this zone is characteristic for the lower part of the Glozhene Formation at the Barlya, Komshtitsa, and Gintsi sections (Lakova, 1994; Lakova et al., 2007; Lakova and Petrova, 2013). This was also confirmed in the Yavorets section. The thickness of the Crassicollaria Zone, however, reaches $\sim 24 \mathrm{~m}$ (samples Ya 31-Ya 40), which suggests a greater rate of sedimentation in comparison to the sections mentioned above and located more westerly. The base of the Crassicollaria Zone is defined at the FO of hyaline-walled calpionellids (normally, the FO of Tintinnopsella carpathica). The vertical distribution of calpionellid species within this zone confirmed that the recent subdivision into three subzones, namely Remanei, Intermedia, and Colomi (Fig. 3), which was introduced by Pop (1994b) and applied in the Western Carpathians and France (e.g., Reháková in: Wimbledon et al., 2013), fits better to the succession of bioevents than all previously used subzonal divisions.

\section{Tintinnopsella remanei Subzone}

This subzone occurs in the lower but not the lowermost part of the Glozhene Formation, its thickness being about $10.0 \mathrm{~m}$ (samples Ya 31-Ya 35) (Fig. 3). Its base is defined at the first occurrence of Tintinnopsella carpathica and, as a whole, at the appearance of hyaline-walled calpionellids. Within the subzone, Crassicollaria intermedia, Crassicollaria brevis, Crassicollaria massutiniana, and Crassicollaria parvula also make their FOs. Praetintinnopsella andrusovi and all representatives of Dobeni and Boneti subzones disappeared (Figs 3, 6-8). A specific feature of the Tintinnopsella remanei Subzone in the Yavorets section is an earlier occurrence of calpionellid species that generally make their FOs above the top of this subzone (e.g., Crassicollaria parvula, Crassicollaria brevis, and Calpionella alpina). Indeed, these three species are represented by single to rare, atypical specimens.

\section{Crassicollaria intermedia Subzone}

Crassicollaria intermedia Subzone was herein used to embrace the middle part of the latest 

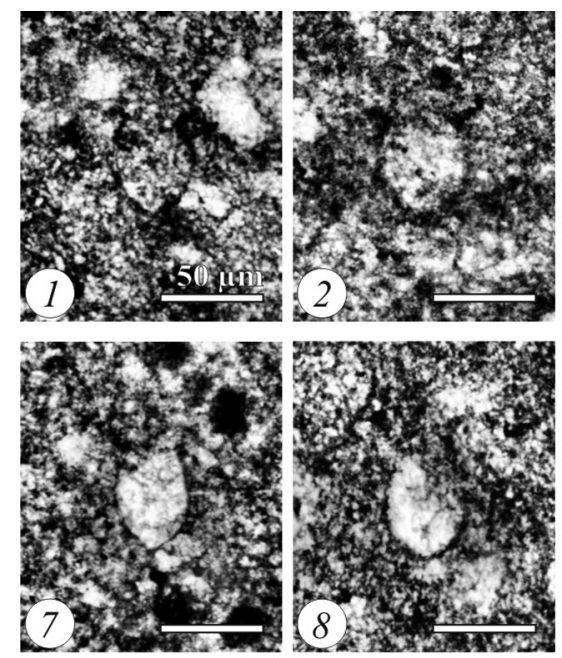

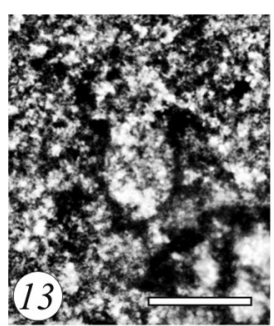
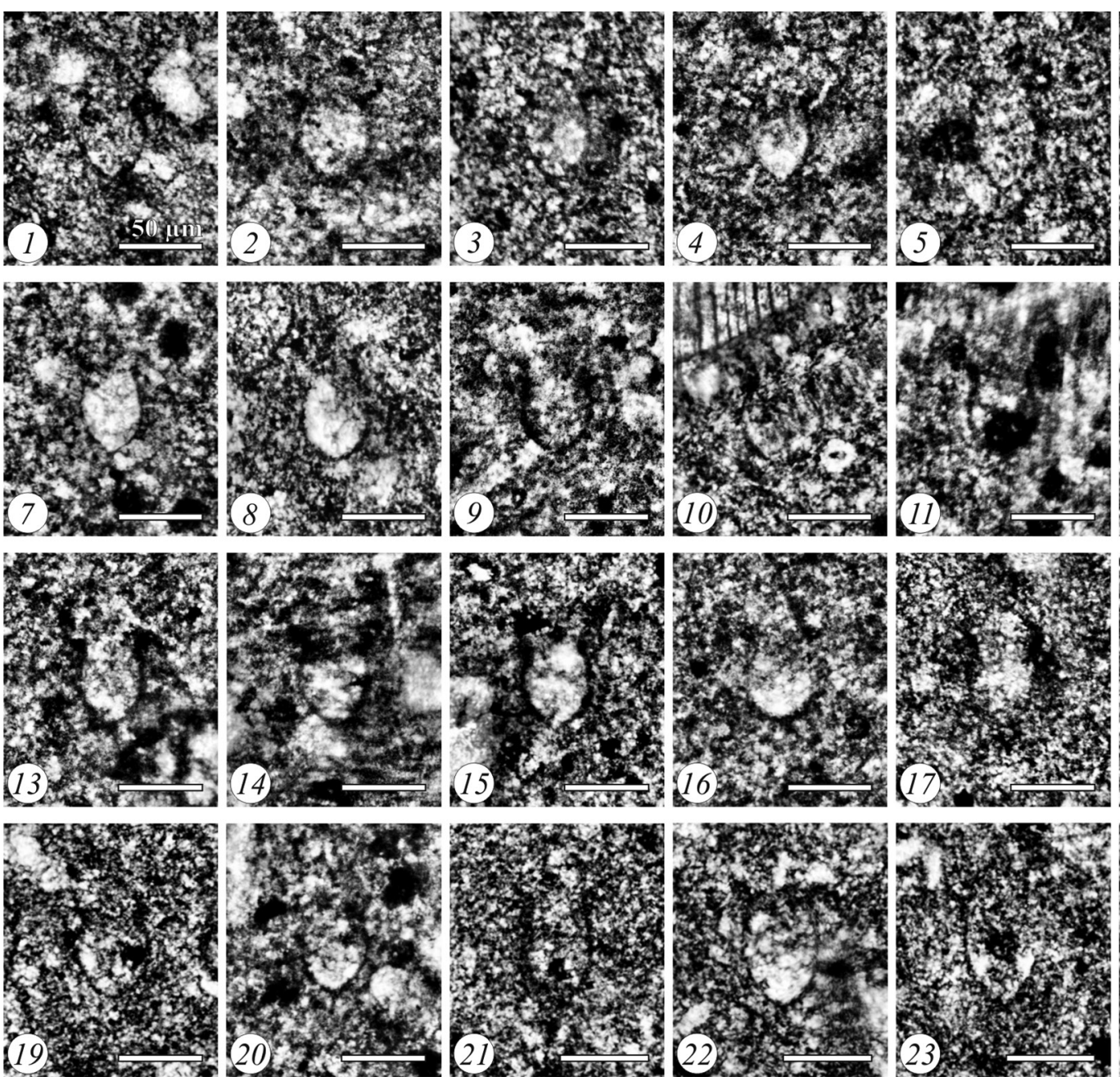

t.
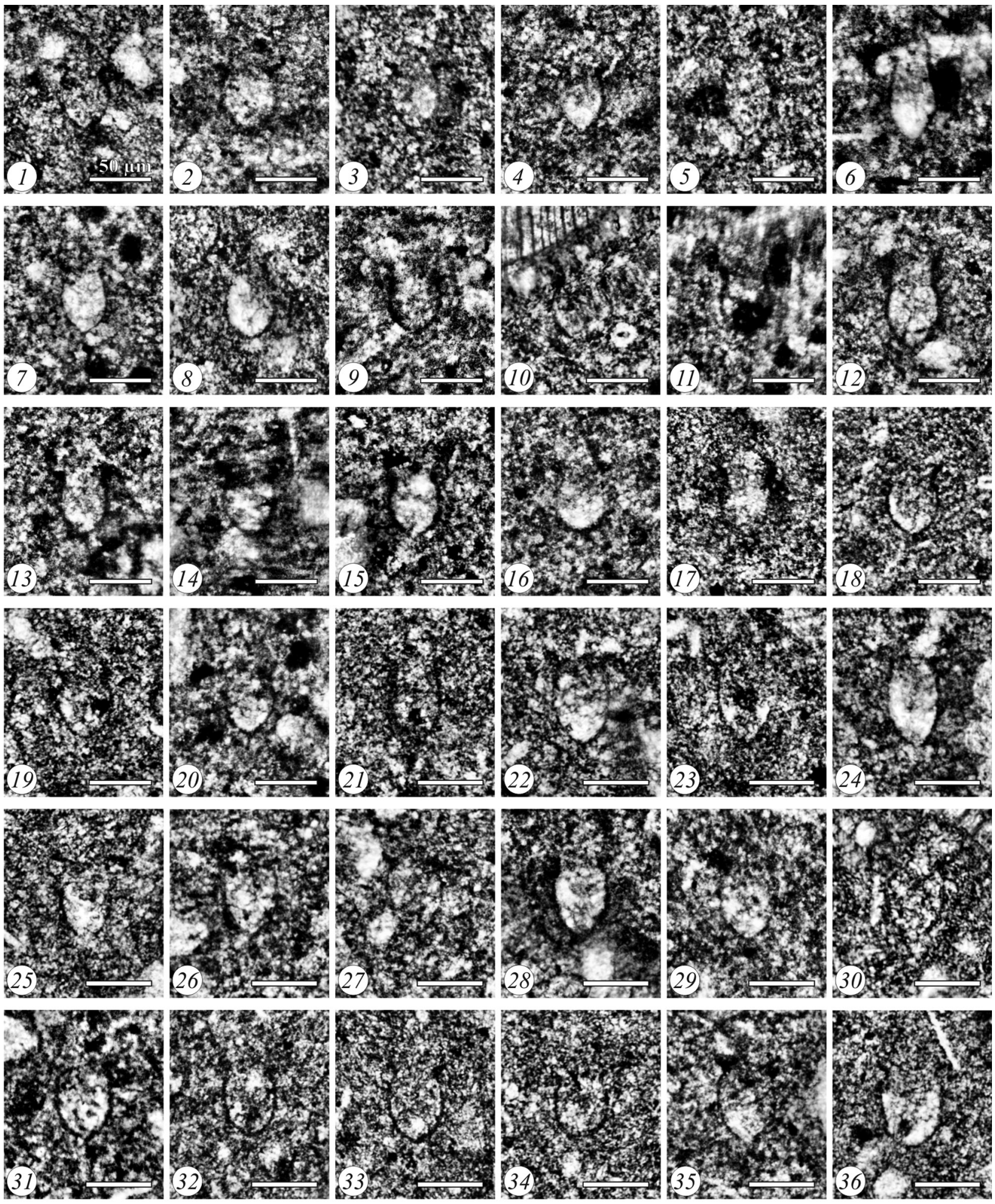

\section{X.}

(31)

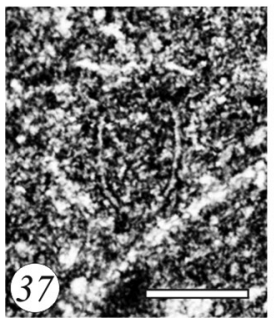
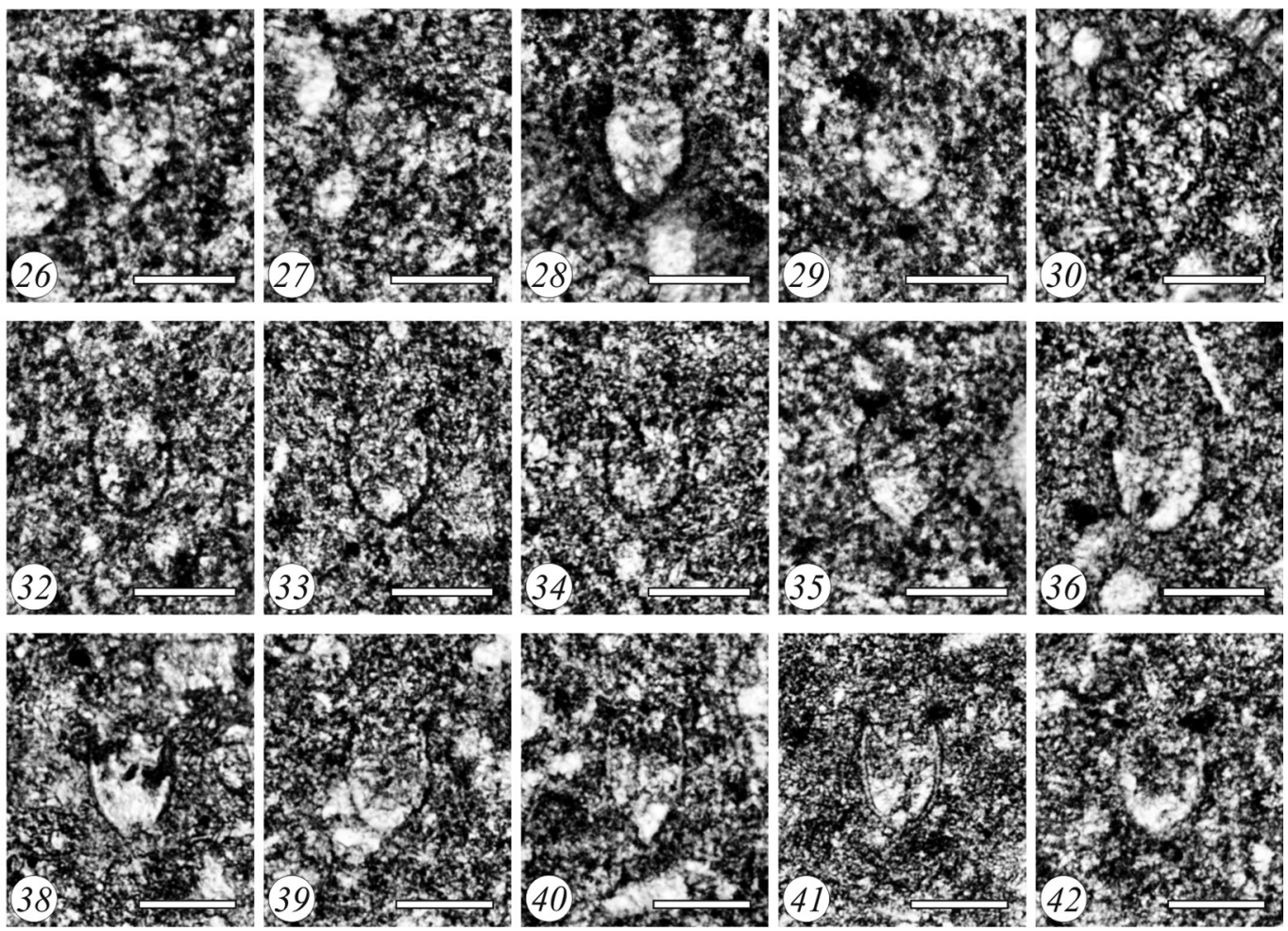
Fig. 5. Chitinoidellids and semichitinoidellids from the Yavorets section: 1-4) Chitinoidella boneti, sample Ya 31 (1), sample Ya 32 (2), sample Ya 31 (3, 4); 5-8) Chitinoidella elongata, sample Ya 31 (5, 7, 8), sample Ya 28 (6); 9-11) Dobeniella bermudezi, sample Ya 29 (9), sample Ya 30 (10), sample Ya 28 (11); 12) Dobeniella lubimovae, sample Ya 29; 13-16) Dobeniella cubensis, sample Ya 29 (13, 15), sample Ya 28 (14), sample Ya 31 (16); 17-20) Almajella cristobalensis, sample Ya 28 (17), sample Ya 29 $(18,19)$, sample Ya 31 (20); 21-24) Chitinoidella popi, sample Ya 28 (21), sample Ya 31 (22-24); 25-30) Chitinoidella carthagensis, sample Ya 31 (25, 26, 28, 29), sample Ya 32 (27), sample Ya 30 (30); 31-36) Chitinoidella hegarati, sample Ya 29 (31-34), sample Ya 31 (35), sample Ya 30 (36); 37-42) Praetintinnopsella andrusovi, sample Ya 30 (37-39), sample Ya 31 (40-42). The scale bar is $50 \mu \mathrm{m}$.

Tithonian Crassicollaria Zone. It confines strata between the FOs of Calpionella grandalpina and Crassicollaria colomi (see Pop, 1994b). Its thickness is $5.5 \mathrm{~m}$ (samples Ya 36-Ya 37) (Fig. 3). In the studied section, Crassicollaria brevis shows a well-pronounced level of abundance in the middle and upper parts of the Crassicollaria Zone (Intermedia+Colomi subzones). The Crassicollaria intermedia Subzone, as a whole, is characterized by diversity and abundance of crassicollarians (Crassicollaria intermedia, Crassicollaria massutiniana, Crassicollaria brevis, and Crassicollaria parvula) (Fig. 7). The base is defined by the FO of the large variety of Calpionella alpina (see Remane et al., 1986; Pop, 1994b), widely known and accepted as a distinct species, i.e., Calpionella grandalpina (see Nagy, 1986; Houša, 1987; Reháková, 1995; Reháková and Michalík, 1997; Lakova et al., 1999; Michalík and Reháková, 2011; Benzaggagh et al., 2012; Petrova et al., 2012; Lakova and Petrova, 2013; Wimbledon et al., 2013; Michalík et al., 2016, 2019; Atasoy et al., 2018; Košták et al., 2018; Kowal-Kasprzyk and Reháková, 2019; Svobodová et al., 2019) (Figs 3, 6). Calpionella alpina (the small spherical form), which makes its FO just below the base of the Intermedia Subzone, progressively increases in abundance so that, at the top of the Crassicollaria Zone, it is as abundant as Calpionella grandalpina and, at the base of the Calpionella Zone, Calpionella alpina practically dominates the association.

\section{Crassicollaria colomi Subzone}

The base is defined at the FO of Crassicollaria colomi. The subzone represents the topmost Tithonian, its thickness here being $8.5 \mathrm{~m}$ (samples $\mathrm{Ya}$ 38-Ya 40) (Fig. 3). The association is rich in crassicollarians, such as Crassicollaria intermedia, Crassicollaria brevis, and Crassicollaria massutiniana, ranging from the underlying subzones. Calpionella grandalpina and Calpionella alpina are, however, also common. At the top of the subzone, a characteristic form with a highly elongated lorica, which has commonly been reported as "Calpionella elliptalpina" or as "homeomorph of Calpionella ellip- tica" in older publications, manifests a short range just below the Crassicollaria/Calpionella zonal boundary (Figs 3, 6).

\section{Calpionella Zone}

The Calpionella Zone (Alpina and Remaniella subzones) corresponds to a 38.5-m thick interval of the Glozhene Formation at the Yavorets section (samples Ya 41-Ya 52, see Fig. 3). The lower boundary of the zone is placed at the explosion of the uniformly shaped spherical variety of Calpionella alpina. This is the primary marker for fixing the $\mathrm{J} / \mathrm{K}$ boundary (see Wimbledon, 2017). The Crassicollaria/Calpionella zonal boundary, respectively the $\mathrm{J} / \mathrm{K}$ boundary, is traced at about $28 \mathrm{~m}$ above the base of the Glozhene Formation.

\section{Calpionella alpina Subzone}

The base of the Calpionella alpina Subzone is defined, and is herein documented by, the sudden increase of Calpionella alpina, and the abrupt decline of Calpionella grandalpina and all crassicollarians except for the longer-ranging Crassicollaria parvula. The elongated elliptical form Calpionella "elliptalpina" never occurs above the top of the Crassicollaria Zone. The last rare to single specimens of Crassicollaria massutiniana, Crassicollaria brevis, Crassicollaria intermedia and Calpionella grandalpina were observed within the Calpionella alpina Subzone (above sample Ya 41). Normally, Tintinnopsella carpathica, Crassicollaria parvula, and Calpionella alpina occur throughout the subzone, and Crassicollaria colomi disappears in the midupper part. Three subsidiary bioevents have been registered in the lower-middle Alpina Subzone, namely the FOs of Calpionella minuta, Tintinnopsella doliphormis, and Calpionella sp. A. The subzone is of significant thickness, estimated to $35 \mathrm{~m}$, samples Ya 41-Ya 50 (Figs 3, 6-8).

\section{Remaniella ferasini Subzone}

The Remaniella ferasini Subzone covers a 3.5-m thick interval of the Glozhene Formation (samples 

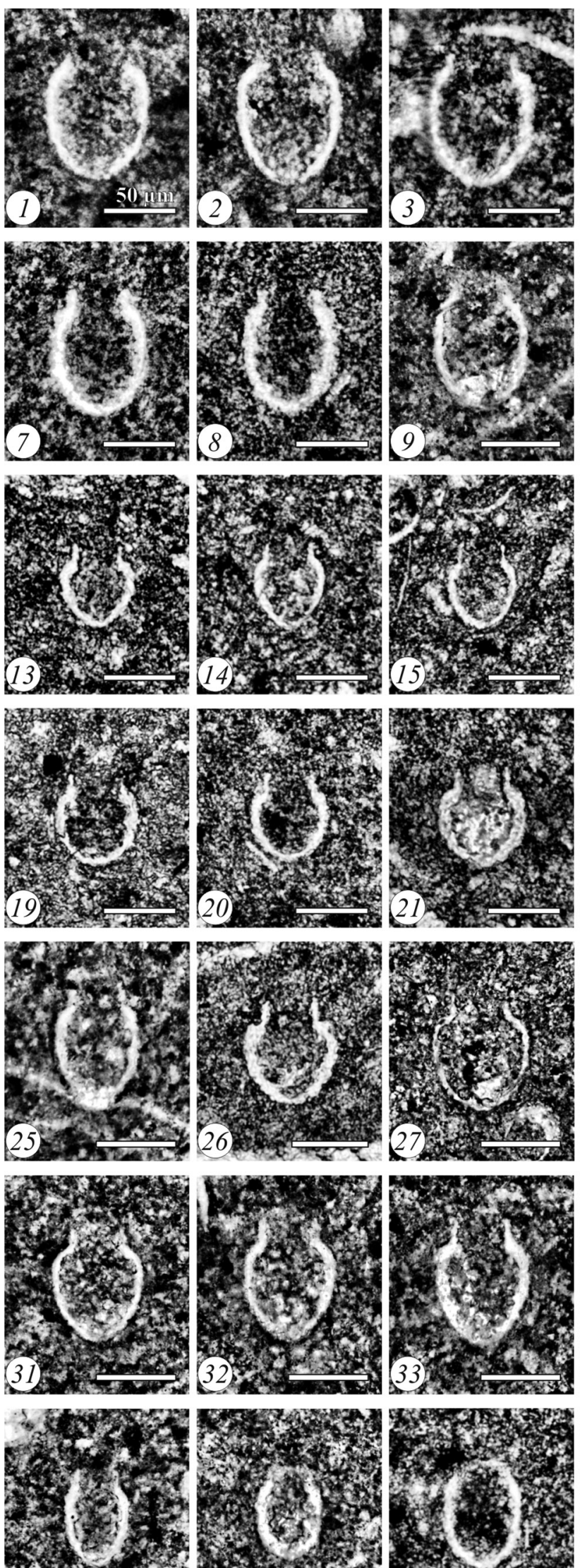

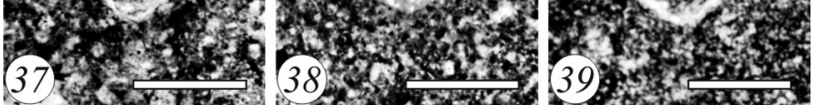
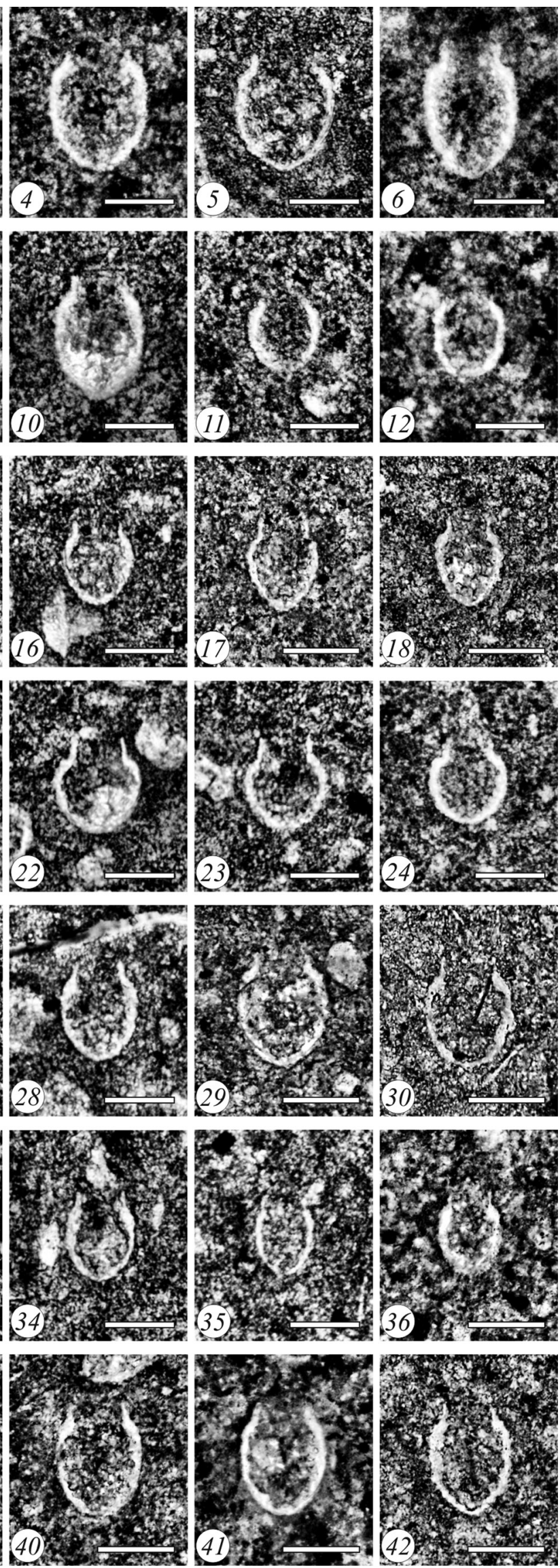
Fig. 6. Calpionellids of the genus Calpionella of the Yavorets section: 1-5) Calpionella grandalpina, sample Ya 36; 6-10) Calpionella elliptalpina, sample Ya 39 (6-8), sample Ya 40 (9, 10); 11-18) Calpionella alpina (small variety), sample Ya 37 (11), sample Ya 36 (12), sample Ya 47 (13-16), sample 48 (17), sample Ya 51 (18); 19-24) Calpionella alpina (small spherical form), sample Ya 44 (19-21), sample Ya 46 (22-24); 25-33) Calpionella alpina (large variety), sample Ya 40 (25), sample Ya 44 (26), sample Ya 47 (28), sample Ya 48 (30), sample 51 (29, 31-33), sample 52 (27); 34-38) Calpionella minuta, sample Ya 45 (34), sample Ya 47 (35), sample Ya 51 (36-38); 39-42) Calpionella sp. A (transitional form between Calpionella alpina and Calpionella elliptica), sample Ya 45 (39), sample Ya 51 (40-42). The scale bar is $50 \mu \mathrm{m}$.

Ya 51 to Ya 52, top of the section; see Fig. 3). The lower boundary is defined by the first record of the index-species Remaniella ferasini. The FOs of Remaniella duranddelgai and Remaniella colomi were also recorded at the same level. The association of the subzone is complemented by Tintinnopsella carpathica, Crassicollaria parvula, Calpionella alpina, Calpionella minuta, Calpionella sp. A, as well as by rare specimens of Tintinnopsella doliphormis (Figs 6, 8).

\section{NOTES ON CALCAREOUS DINOCYST BIOSTRATIGRAPHY}

Calcareous dinocysts are of primary importance for the biostratigraphy of the lower part of the Yavorets section, which includes the top of the Yavorets Formation and the main body of the Gintsi Formation. This will be the subject of another publication. In the herein described stratigraphic interval, three calcareous dinocyst zones have been determined, namely the Colomisphaera tenuis, Colomisphaera fortis and Stomiosphaerina proxima zones (Fig. 3). Definitions of the zones follow that of Ivanova (in: Lakova et al., 1999).

\section{Colomisphaera tenuis Zone}

The lower boundary is defined at the FO of the index-species, which coincides with the appearance of chitinoidellids (sample Ya 24). Two species are confined in the Colomisphaera tenuis Zone: Colomisphaera cieszynica and Colomisphaera radiata. Crustocadosina semiradiata semiradiata makes its $\mathrm{FO}$ at the base of this zone.

Longer-ranging calcareous dinocysts from the Oxfordian and Kimmeridgian continue occurring in this zone, e.g., Colomisphaera lapidosa, Colomisphaera carpathica, Colomisphaera nagyi, Colomisphaera pieniniensis, Committosphaera sublapidosa, and Cadosina fusca fusca (Figs 3, 9). Two of them, Colomisphaera nagyi and Colomisphaera pieniniensis, disappear in the upper part of the zone. Of interest is mentioning the presence of Cadosina fusca fusca and Crustocadosina semiradiata semi- radiata as auxiliary criteria for tracing the base of this zone.

The Colomisphaera tenuis Zone in this section corresponds to the topmost Gintsi Formation and the basal strata of the Glozhene Formation. Its thickness is 13.5-14 m (from samples Ya 23 to Ya 30). The zone correlates directly with the Chitinoidella and Praetintinnopsella zones, i.e., the lower/upper Tithonian boundary is to be traced above the FO of Colomisphaera tenuis (Fig. 3).

\section{Colomisphaera fortis Zone}

The FO of Colomisphaera fortis marks the lower boundary of this zone. With small exceptions, the calcareous dinocyst association is the same as that of the Colomisphaera tenuis Zone (see Figs 3, 9). The last occurrence (LO) of Colomisphaera tenuis is at the top of the Colomisphaera fortis Zone. The thickness is $\sim 4.0 \mathrm{~m}$ (samples Ya 31-Ya 33). In terms of calpionellid biostratigraphy, the Colomisphaera fortis Zone directly correlates with the lower half of the Tintinnopsella remanei Subzone and is thus a reliable evidence of the early late Tithonian.

\section{Stomiosphaerina proxima Zone}

The Tithonian/Berriasian boundary corresponds to the lower part of the Stomiosphaerina proxima Zone. The FO of the index-species marks the lower boundary at the level of sample Ya 34 (Fig. 3). Besides the calcareous dinocyst associations mentioned in the Colomisphaera tenuis Zone, additional species which occur in the Stomiosphaerina proxima Zone are Colomisphaera fortis, Stomiosphaera misolensis, Stomiosphaera acculeata, Cadosina fusca cieszynica, and Colomisphaera lucida (Fig. 9). Actually, the latter three species are rather characteristic for the Berriasian. The upper boundary of Stomiosphaerina proxima Zone has not been determined in the section studied. Normally, it is characterized by the FO of Stomiosphaera wanneri Borza, 1969 in the upper Berriasian, e.g., in the Barlya section (see Grabowski et al., 2016). 

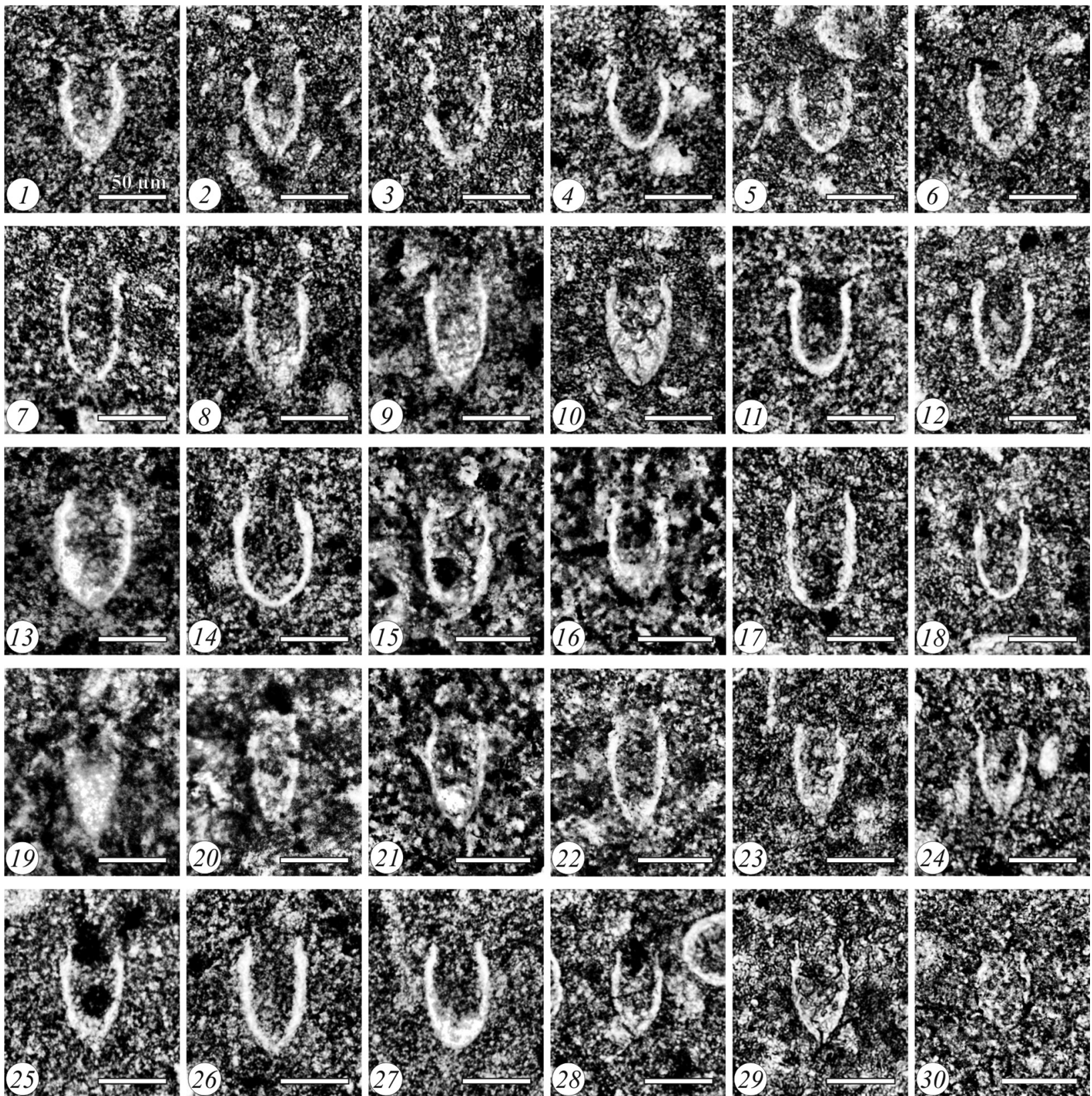

Fig. 7. Calpionellids of the genus Crassicollaria from the Yavorets section: 1-6) Crassicollaria brevis, sample Ya 37 (1, 2), sample Ya 38 (3), sample Ya 35 (4, 5), sample Ya 45 (6); 7-12) Crassicollaria intermedia, sample Ya 36 (7-10), sample Ya 33 (11), sample Ya 35 (12); 13-18) Crassicollaria massutiniana, sample Ya 36 (13, 14), sample Ya 39 (15, 16), sample Ya 35 (17), sample Ya 44 (18); 19-24) Crassicollaria colomi, sample Ya38 (19), sample Ya 39 (20), sample Ya 40 (21), sample Ya 43 (22), sample Ya 44 (23), sample Ya 45 (24); 25-30) Crassicollaria parvula, sample Ya 37 (25, 26), sample Ya 36 (27), sample Ya 45 (28), sample Ya 44 (29), sample Ya 52 (30). The scale bar is $50 \mu \mathrm{m}$.

\section{CARBONATE MICROFACIES}

\section{Description}

A set of successive microfacies (MF) has been identified through the studied section, based on the predominant microfossil constituents. They correspond to the so-called paleontological microfacies of Re- háková et al. (2011). From the base upwards, these are: Saccocoma MF (Gintsi Formation, lower and upper Tithonian); Globochaete alpina MF (Glozhene Formation, upper Tithonian), and calpionellid MF (Glozhene Formation, upper Tithonian and lower Berriasian).

The Gintsi Formation is generally characterized by nodular limestones. Its equivalents are the "am- 

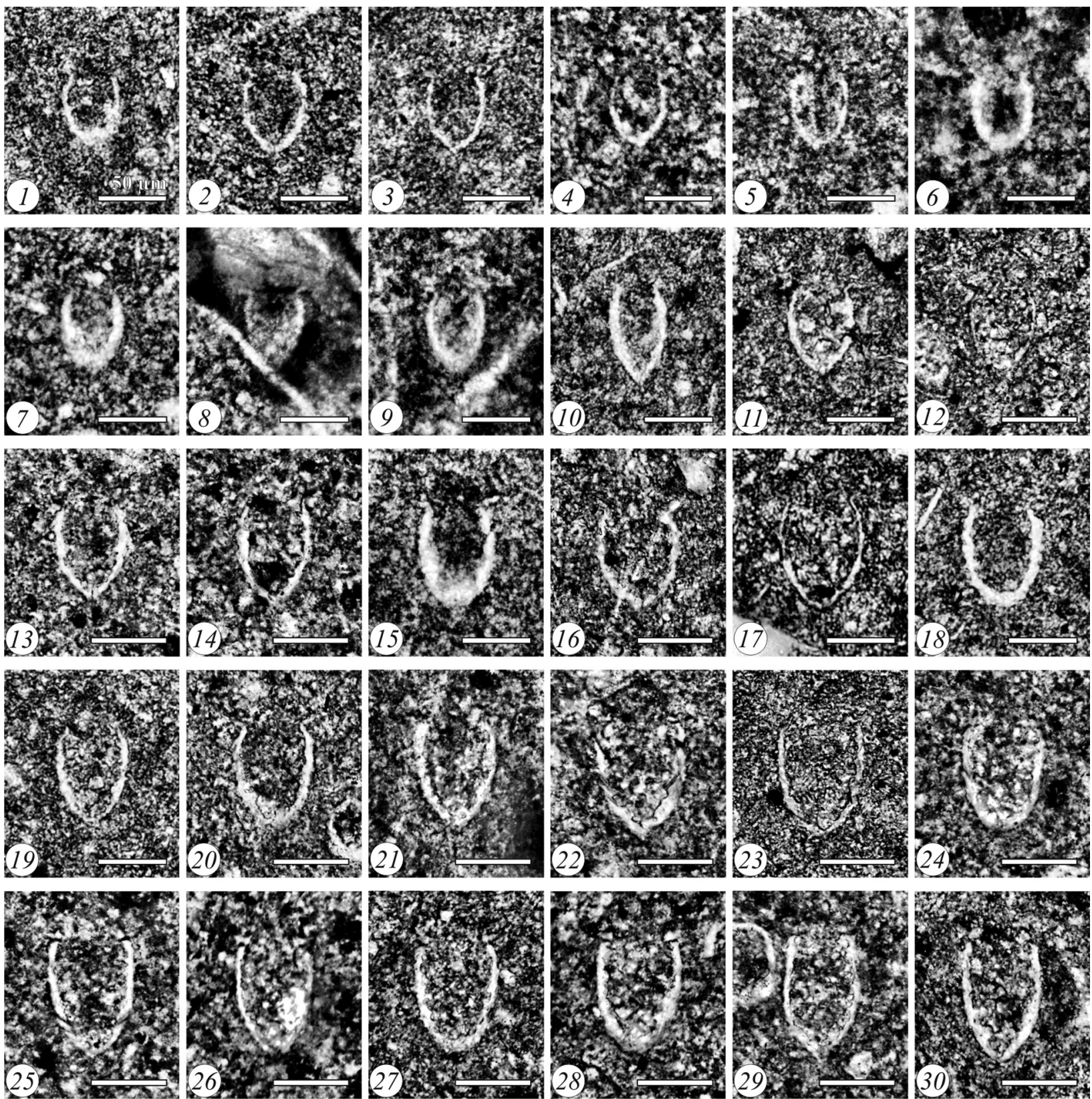

Fig. 8. Calpionellids of the genera Tintinnopsella and Remaniella from the Yavorets section: 1-6) Tintinnopsella remanei, sample Ya 33 (1), sample Ya 34 (2-5), sample Ya 35 (6); 7-17) Tintinnopsella carpathica (different varieties), sample Ya 31 (7), sample Ya 35 (8), sample Ya 33 (9), sample Ya 44 (10), sample Ya 47 (11, 17), sample Ya 43 (13), sample Ya 49 (16), sample Ya 39 (14), sample Ya 37 (15), sample Ya 52 (12); 18-21) Tintinnopsella doliphormis, sample Ya 44 (18), sample Ya 47 (19), sample Ya 48 (20), sample Ya 51 (21); 22-24) Remaniella ferasini, sample Ya 52 (22, 23), sample Ya 51 (24); 25-28) Remaniella duranddelgai, sample Ya 51; 29, 30) Remaniella colomi, sample Ya 51. The scale bar is $50 \mu \mathrm{m}$.

monitico rosso superiore"-type pelagic limestones. The indicative microfossil for them is the pelagic crinoid Saccocoma that defines the Saccocoma MF. It is represented by radiolarian-Saccocoma wackestone (Ya 23, Ya 24 and Ya 27); radiolarianGlobochaete-Saccocoma wackestone (Ya 25 and Ya 26), and radiolarian-Globochaete-Saccocoma wackestone with intraclasts (Ya 28) (Figs 3, 10). It is worth mentioning that the interval from samples Ya 24 to Ya 28, around the lower/upper Tithonian boundary, contains diverse chitinoidellids, although their quantity could not be used to characterize a certain microfacies because the radiolarians, globochaetids and Saccocoma considerably prevail over 

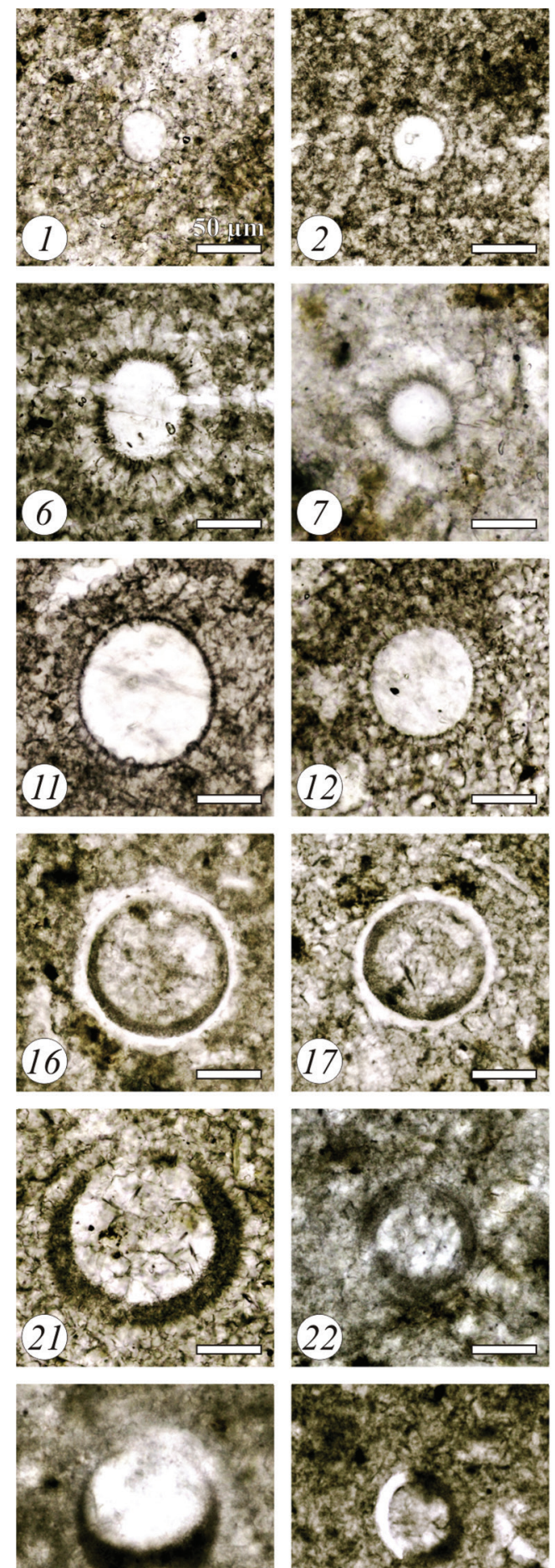

26
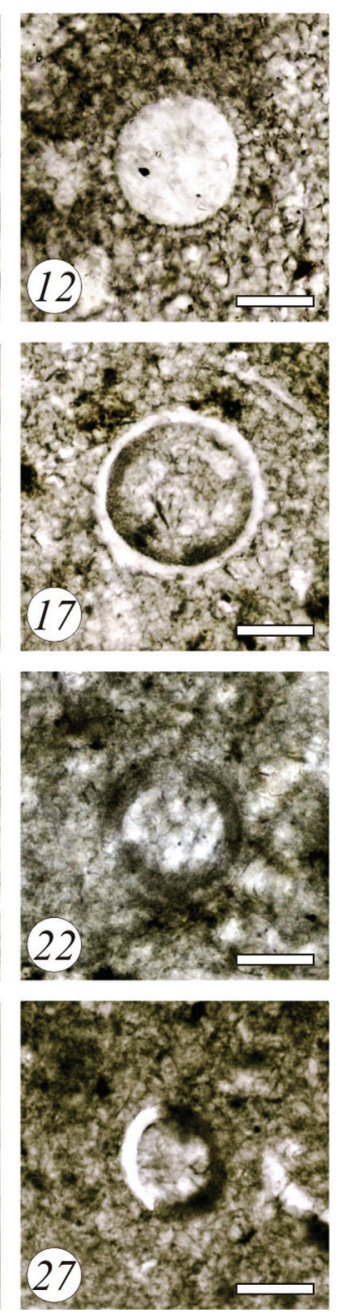
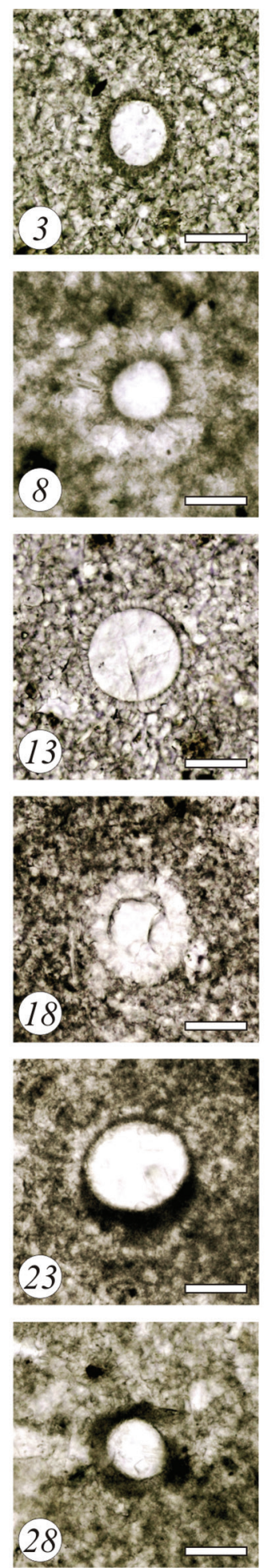
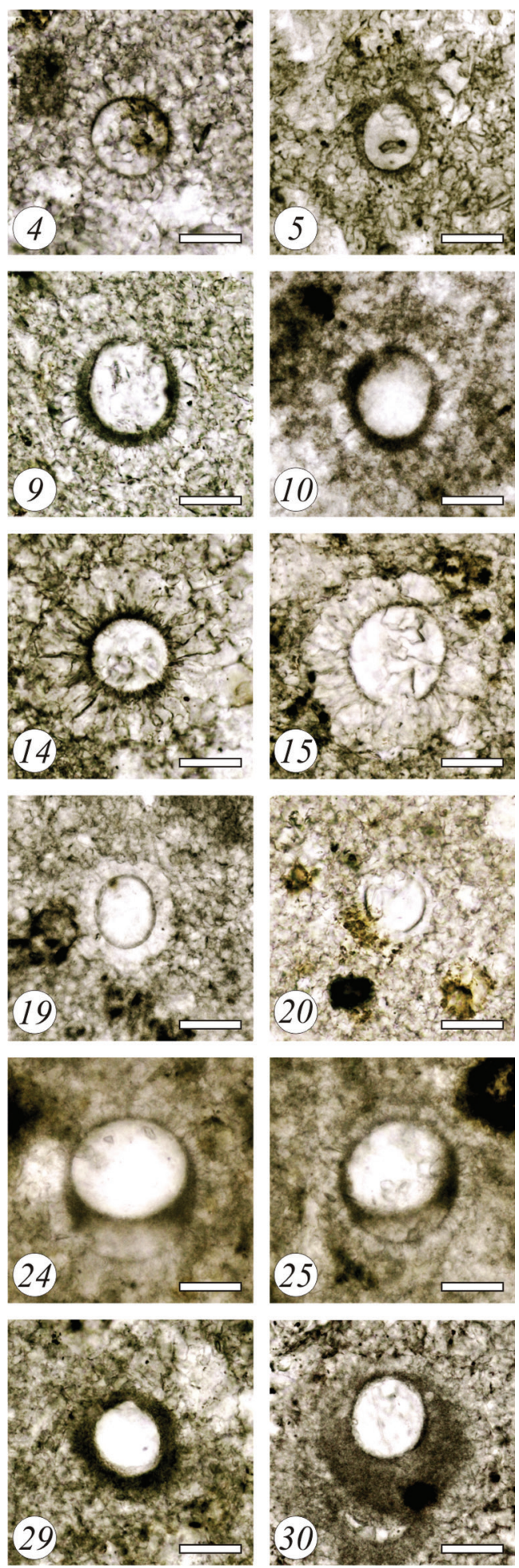

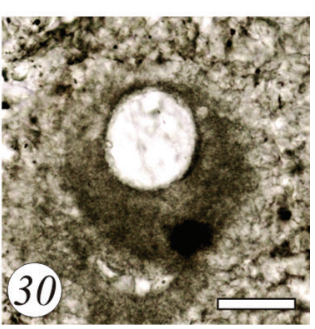

Fig. 9. Calcareous dinoflagellate cysts from the Yavorets section: 1, 2) Colomisphaera tenuis, sample Ya 24 (1), sample Ya 32 (2); 3) Colomisphaera radiata, sample Ya 24; 4) Colomisphaera lapidosa, sample Ya 25; 5) Colomisphaera pieniniensis, sample Ya 25; 6) Colomisphaera nagyi, sample Ya 25; 7, 8) Colomisphaera cieszynica, sample Ya 24 (7), sample Ya 33 (8); 9, 10) Committosphaera sublapidosa, sample Ya 24 (9), sample Ya 29 (10); 11-13) Colomisphaera fortis, sample Ya 41 (11), sample Ya 35 (12), sample Ya 44 (13); 14, 15) Colomisphaera carpathica, sample Ya 24 (14), sample Ya 47 (15); 16, 17) Stomiosphaerina proxima, sample Ya 34 (16), sample Ya 37 (17); 18, 19) Colomisphaera lucida, sample Ya 46 (18), sample Ya 48 (19); 20) Stomiosphaera misolensis, sample Ya 48; 21, 22) Crustocadosina semiradiata semiradiata, sample Ya 50 (21), sample Ya 30 (22); 23-26) Crustocadosina semiradiata olzae, sample Ya 35; 27-29) Cadosina fusca fusca, sample Ya 25 (27), sample Ya 29 (28), sample Ya 52 (29); 30) Cadosina fusca cieszynica, sample Ya 43. The scale bar is $50 \mu \mathrm{m}$. 

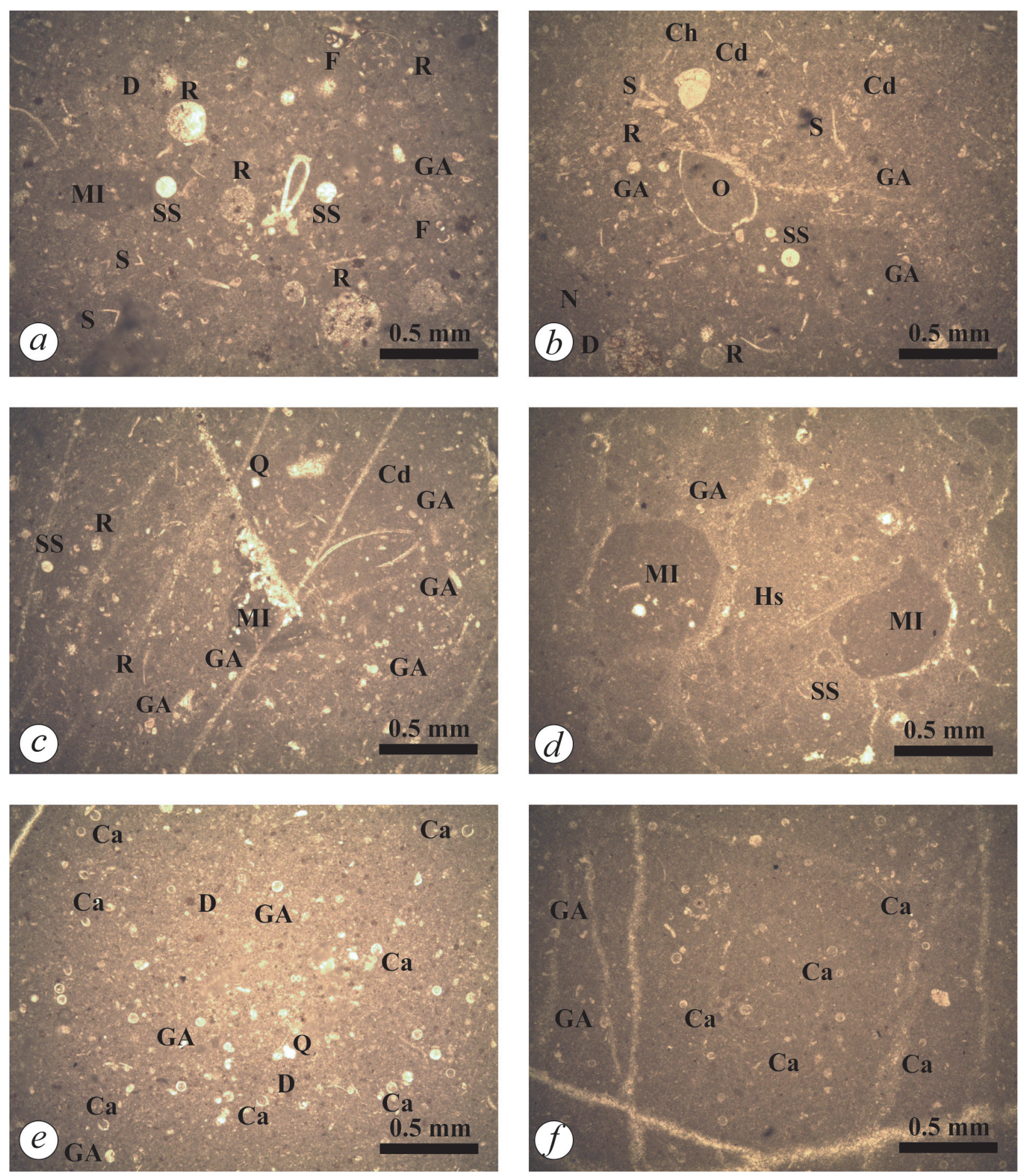

Fig. 10. Microphotographs of Saccocoma $(a, b)$, Globochaete $(c, d)$ and Calpionellid $(e, f)$ microfacies from the Yavorets section: a) Radiolarian-Saccocoma-Globochaete wackestone - predominantly calcified radiolarians (R), sponge spicules (SS), Globochaete alpina (GA) and rare Saccocoma remains (S), foraminifera (F), single dolomite rhombohedra (D), single micritic intraclasts (MI) in micrite matrix. Sample Ya 28, Gintsi Fm.; b) Radiolarian-Globochaete-Saccocoma wackestone - boundary between a part of a nodule (N) containing rare calcified radiolarians (R), sponge spicules (SS), Globochaete alpina (GA), ostracod test (O) and groundmass enriched predominantly in Saccocoma fragments (S), Globochaete alpina (GA) and rare calcareous dinocysts (Cd), and chitinoidellids (Ch). Sample Ya 25, Gintsi Fm.; c) Radiolarian-Saccocoma-Globochaete wackestone - mainly calcified radiolarians (R), sponge spicules (SS), Globochaete alpina (GA) and single quartz grains (Q) and rare calcareous dinocysts (Cd), micritic intraclasts (MI). Sample Ya 29, Glozhene Fm.; d) Radiolarian-Globochaete wackestone - small micrite intraclasts (MI) and single sponge spicules (SS), Globochaete alpina (GA) and rare remains of holothurian sclerites (Hs). Sample Ya 33, Glozhene Fm.; e) Calpionellid wackestone - predominantly calpionellids (Ca), rare Globochaete alpina (GA), tiny dolomite rhombohedra (D) and single quartz grains (Q) in micrite matrix. Sample Ya 42, Glozhene Fm.; f) Calpionellid wackestone - predominantly calpionellids (Ca) and rare Globochaete alpina (GA) in micrite matrix. Sample Ya 52, Glozhene Formation. Note: All images are in plane-polarized light. 
the chitinoidellids. The pelagic crinoid oscicles still occur over the Saccocoma MF, although in considerably reduced amount.

The Glozhene Formation, similarly to all corresponding Biancone-type pelagic limestones in the Tethyan Domain, is rich in Globochaete alpina Lombard, 1945 and calpionellids. Consequently, the dominating microfacies are Globochaete alpina MF (the base of the Glozhene Formation) and the calpionellid MF (Glozhene Formation, without its first $14 \mathrm{~m}$ ) (see Figs 3, 10). It is only at the basal part of the formation (Ya 29 to Ya 35), where the calpionellids of the Praetintinnopsella Zone and the Remanei Subzone are still scarce, that the Globochaete alpina wackestone and radiolarian-spicule wackestone were determined, respectively. The calpionellid MF is mainly represented by calpionellid wackestone to mudstone (from Ya 36 to Ya 52). This microfacies corresponds to SMT 3-Calp. (deep basinal facies, Facial zone 1) of Flügel (2004).

\section{Interpretation of the depositional environment}

The nodular limestones of the Gintsi Formation were formed on a submarine rise (structural high or pelagic platform), as can be seen from many examples from the Tethyan Domain (Flügel, 2004, and references therein). Nodularization of the original sediments is a diagenetic process well described by Clari and Martire (1996). Two types of nodular limestone were recognized in the studied section: incipient nodular and nodular. Some nodule boundaries in the incipient nodular limestones are sharp but most commonly diffuse, with a gradual transition to the matrix. The matrix of the nodular limestones (rich in Saccocoma fragments) possesses pale rose color and nodules are surrounded by it.

The micritic limestones of the Glozhene Formation contain calpionellids, Globochaete alpina, radiolarians, and sponge spicules and, most probably, were formed in a deep-water basinal environment (SMT 3, FZ 1, see Flügel, 2004) after drowning of the pelagic platform. These limestones are also very characteristic of the Tethyan Domain as Biancone (Majolica) facies. The sediments were deposited above the calcite compensation depth (CCD) and below the aragonite compensation depth (ACD). This depth range is herein indicated by the presence of calcite skeletons (aptychi, calcareous nannofossils, sometimes brachiopods) and the lack of aragonite ones (Wieczorek, 1988).

The most widely accepted concept is that the nodular limestones were accumulated on a submarine structural high (pelagic swell, pelagic platform) (see Jenkyns, 1974; Jach, 2007). On the other hand,
Flügel (2004) refers limestones with calpionellids to SMT 3-Calp. (deep basinal facies, Facial zone 1).

\section{DISCUSSION}

\section{Morphological diversity of the genus Calpionella}

The genus Calpionella is characterized by a considerable variety and changes in the size and shape of the lorica in time. Its evolutionary lineage began during the late Tithonian and terminated during the early Valanginian. The "bloom" of the genus Calpionella corresponds to the upper Tithonian (Crassicollaria Zone) and lower Berriasian (Calpionella Zone).

The first representatives of the genus appear at the top of the Remanei Subzone of the Crassicollaria Zone. These are the first Calpionella alpina. The specimens are small to medium in size, with a lesspronounced collar or without collar (see Figs 3, 6.11, 6.12). The lower boundary of the overlying Intermedia Subzone is accepted to be placed at the FO of Calpionella grandalpina, or "large, somewhat elongated variety" in the sense of Remane et al. (1986). This is a big-size form, having a large, almost isometric lorica with maximum width at the shoulder, and a straight collar (see Figs 3, 6.1-6.5). Together with Calpionella grandalpina, Calpionella alpina with a well-visible collar also occurs in the Intermedia Subzone (Fig. 6.25).

The FO and LO of the short-living form Calpionella "elliptalpina" is marked in the Colomi Subzone (uppermost part of the Crassicollaria Zone). This form is characterized by a big size and elongated lorica (Figs 3, 6.6-6.10). The species has often been described in the past as a homeomorph of the "Calpionella elliptica" or has been confused with the real Calpionella elliptica Cadisch, 1932. Lakova (1994) offered the extinction of the species as an additional criterion for the Jurassic/Cretaceous boundary. Kowal-Kasprzyk and Reháková (2019) made a thorough morphometric analysis of loricae of Calpionella alpina (small spherical form), Calpionella grandalpina, and Calpionella elliptalpina.

The main criterion for tracing the base of the Berriasian is the "explosion" of the small spherical form of Calpionella alpina (Wimbledon, 2017) (Figs 3, 6.19-6.24). This form is dominant in the lower part of the Alpina Subzone of the Calpionella Zone. It co-occurs with other small- to mediumsized, more or less isometric or elliptical varieties of Calpionella alpina (see Remane, 1963, and Fig. 6.13-6.18, 6.26-6.33), the latter being represented in very small quantities. Their number significantly 
increases at the expense of the spherical-shaped form in the upper part of the Alpina Subzone.

A successive event in the evolution of the genus Calpionella is the appearance of Calpionella minuta in the middle of the Alpina Subzone (Fig. 3). Representatives of this species are of small size, have thin-walled lorica, and are moderately elongated (Fig. 6.34-6.38). The next event in the evolution the genus Calpionella registered in the Yavorets section is the FO of Calpionella sp. A., also in the middle of the Alpina Subzone, shortly after the appearance of the Calpionella minuta (Fig. 3). Remane (1963) called this variety Calpionella sp. This potentially new species is an intermediate form between Calpionella alpina and the real Calpionella elliptica (Fig. 6.39-6.42). Very often, such specimens have been described as Calpionella elliptica, but the former's loricae are shorter, with somewhat convex walls and not as straight as in the typical Calpionella elliptica. The LO of Calpionella sp. A is in the lower part of the Elliptica Subzone of the Calpionella Zone (Grabowski et al., 2016).

\section{Stratigraphical distribution of the genus Crassicollaria}

In contrast to the genus Calpionella, all species of the genus Crassicollaria appear almost simultaneously or within a small time interval in the Crassicollaria Zone. Their peak of abundance and diversity is also related to the Crassicollaria Zone. They gradually disappear within the lower part of the Calpionella Zone. Only one species, Crassicollaria parvula, survived until the late Berriasian (Calpionellopsis Zone, Oblonga Subzone) (Grabowski et al., 2016).

The main problem with representatives of the genus Crassicollaria is their first appearance, their disappearance and the presence or absence of blooming levels of some species. In the past, it has been assumed that the first crassicollarians appear in the Remanei Subzone and they belong to the species Crassicollaria intermedia and Crassicollaria massutiniana. The FOs of the other species, such as Crassicollaria parvula, Crassicollaria brevis, and Crassicollaria colomi, were assumed as characteristic of the Intermedia Subzone or its equivalents (see Remane, 1963; Remane et al., 1986; Reháková, 1995; Reháková and Michalík, 1997; Lakova et al., 1999; Lakova and Petrova, 2013). However, the accumulated data in recent years (Andreini et al., 2007; Reháková et al., 2011; Elbra et al., 2018; Košták et al., 2018; Svobodová et al., 2019) confirm Pop's (1998b) data from the South Carpathians that, in the Remanei Subzone, there are almost si- multaneous appearances of Crassicollaria parvula, Crassicollaria intermedia, Crassicollaria massutiniana, and Crassicollaria brevis. Our data from the Yavorets section (Figs 3, 7), as well as from the Barlya section (unpublished data), prove it once more. Pop (1998b) also proposed a newly defined Parvula Subzone as an equivalent of the Remanei Subzone, whose lower boundary is defined by the first occurrence of the index-species. The FO of Crassicollaria colomi has been documented in the upper part of the Crassicollaria Zone in different localities in the Tethyan region, which gave Pop (1994b) reason to define the Colomi Subzone as the third subzone of the Crassicollaria Zone. In the present paper, we use this subzone for the first time, its lower boundary being placed at the FO of Crassicollaria colomi in the Yavorets section (Fig. 3).

Regarding the extinction of species of the genus Crassicollaria, in the past, it has been claimed that Crassicollaria intermedia, Crassicollaria massutiniana, and Crassicollaria brevis disappear at the very top of the Crassicollaria Zone, and only single specimens can be seen at the base of the Calpionella Zone (see Remane, 1963; Remane et al., 1986; Reháková, 1995; Reháková and Michalík, 1997; Lakova et al., 1999; Lakova and Petrova, 2013). The data from Yavorets show that these crassicollarians crossed the Jurassic/Cretaceous boundary, being represented, however, in significantly reduced numbers, then gradually decreasing and disappearing to the middle and upper parts of the Alpina Subzone together with Crassicollaria colomi (Figs 3, 7). This has also been confirmed by Grabowski et al., (2010) in Hungary, by Reháková et al. (2011) in the Pieniny Klippen Belt and the Carpathians in Western Ukraine, and by Skupien and Doupovcová (2019) in the Outer Western Carpathians (Czech Republic).

In the Yavorets section, an acme of Crassicollaria brevis was documented in the upper part of the Crassicollaria Zone (see Fig. 3, samples Ya 37 and Ya 38, Intermedia+Colomi subzones). The same phenomenon has also been noted by Pop (1974) in the South Carpathians in Romania. Based on it, Pop (1974) introduced the Crassicollaria brevis-parvula Subzone. Later on, Pop (1994b) wrote that this event is not always clear enough and constant to be used as a criterion for defining a subzone, but where it exists it can help recognizing the upper part of the Crassicollaria Zone. Another abundance event is the acme of Crassicollaria parvula in the lower part of the Calpionella Zone (see Lakova and Petrova, 2013). Unlike the other sections in the Western Balkan Mts, in the Yavorets section it is not so well expressed. So far, there is evidence of acme of Crassicollaria parvula in other areas of the Tethyan 
region, e.g., Spain (Pruner et al., 2010), the Western Carpathians of Slovakia (Michalík and Reháková, 2011), and the Trans-Danubian Range (Grabowski et al., 2010). Probably, these bloom levels depend on conditions of the depositional environment.

\section{Regional and interregional correlations of the calpionellid zonation}

\section{Regional correlations - Western Balkan Mts}

The determination of the Chitinoidella, Praetintinnopsella, Crassicollaria, and Calpionella zones with their subzones in the Yavorets section offers a more complete litho-/biostratigraphic correlation of the upper Tithonian and lower Berriasian parts of the Gintsi and Glozhene formations, when compared with previous biostratigraphic results from the westerly located sections at Gintsi, Komshtitsa and Barlya (see Lakova, 1994; Lakova et al., 1999, 2007; Lakova and Petrova, 2013). As a whole, the Gintsi/Glozhene Formation boundary is related to the Chitinoidella Zone. The base of the Berriasian, i.e., the base of the Alpina Subzone, is traced in the lower third of the Glozhene Formation. The boundary of the Glozhene Formation with the overlying Salash Formation marks the end of a long-lasting carbonate pelagic cycle (Oxfordian to Berriasian, see Lakova et al., 2007) and corresponds to the Elliptica Subzone of the Calpionella Zone in the sections at Barlya and Komshtitsa. There is a stratigraphic hiatus between the Glozhene and Salash formations in sections Gintsi 1 and Gintsi 2 (Lakova and Petrova, 2013). The Simplex and Oblonga subzones of the Calpionellopsis Zone are missing. It suggests unstable conditions of the sedimentary environment, which predetermines the onset of hemipelagic sedimentation.

In the area of the Iskar River Valley, sandstones have been observed in the interval of the lithological transition between the Glozhene and Salash formations (Mandov, 1972). Later on, Petrova (2010) provided calpionellid data on the age of this event; it corresponds to the Simplex or Simplex/Oblonga subzonal boundary in the sections at Sarbenitsa and Bov, respectively. The herein studied Yavorets section is located only some $2 \mathrm{~km}$ to the east of the Bov section; however, the lithologic boundary between the Glozhene and Salash formations does not crop out. Nevertheless, test sampling from sandycalcareous siltstones in the area beneath Yavorets Peak yielded a diverse calpionellid association of the lower part of the Oblonga Subzone. It may be concluded, therefore, that the present study gives evidence of the introduction of somewhat terrig- enous sedimentation at the same stratigraphic level as in the Bov section of Petrova (2010).

On the territory of eastern Serbia, in the westernmost end of this band of Tithonian and Berriasian pelagic carbonate sediments, the section of Rosomač shows significant similarity with the Barlya section (see Petrova et al., 2012). There is difference in the allochemic content of the correlatives of the Gintsi and Glozhene formations, namely the Pokrovenik and Rosomač limestones, expressed in the presence of allochthonous microfossils redeposited from a neighboring shallow carbonate platform. Recently, confirmation of such a suggestion has come from the study of Carević et al. (2018) of the upper Tithonian pelagic carbonates of the Carpatho-Balkanides in northeastern Serbia. There, in the section of Jelenska Stena, a mixed foraminifercalpionellid microfossil association has suggested a connection with the northerly situated Getic carbonate platform.

\section{Interregional Tethyan correlations}

A thorough review of interregional correlation of the calpionellid zones and subzones herein described can be seen in Lakova and Petrova (2013). Only recently published zonations in Slovakia, Tunisia and Argentina and elsewhere are included in this paper for correlation purposes (e.g., Michalík et al., 2016; Boughdiri et al., 2009; Kietzmann, 2017). Recent chitinoidellid and calpionellid finds have been published from three main domains: Central Tethyan (Europe, Turkey and North Africa), Eastern Tethyan (Iran and Oman), and Western Tethyan (Cuba, Mexico). Chitinoidellids, calpionellids and calcareous dinocysts from Argentina are the first ones from such a remote area as the Pacific Region.

Extensive publications of calpionellid zonations integrated with nannofossil biostratigraphy and magnetostratigraphy from the Carpathian region are characteristic for the present decade. Michalík et al. (2016) presented the Chitinoidella, Crassicollaria and Calpionella zones and their subzones from the Strapková section in the Western Carpathian of Slovakia. In that area, the regional development of ammonitico rosso is the Czorsztyn Formation (with the Malmica calcareous dinocyst Zone overlain by the Dobeni and Boneti subzones), and the Biancone facies is referred to the Pieniny Limestone Formation with the Crassicollaria and Calpionella zones detected. Elbra et al. (2018) and Svobodová et al. (2019) published integrated microfossil zonation, magnetostratigraphy and isotope geochemistry of the Kurovice section in the Czech Republic. The calcareous dinocyst Colomisphaera tenuis Zone, di- 
rectly overlain by the Crassicollaria and Calpionella zones, was recorded. Very recently, integrated stratigraphy of the Snežnica section of the Western Carpathians in Slovakia has been erected (Michalík et al., 2019), where the top of the Czorsztyn Limestone Formation has been assigned to the upper Tithonian (Chitinoidella, Praetintinnopsella, and Crassicollaria zones), and the Pieniny Limestone Formation - to the top Crassicollaria and Calpionella zones. Kowal-Kasprzyk $(2014,2018)$ reported on chitinoidellids of five genera mainly from the Boneti Zone, found in the exotic limestones of the Silezian Nappe in the Polish Outer Carpathians. In the Tatra Mts (Central Western Carpathians in Poland and Slovakia), Jach et al. (2012) reported on the presence of the Dobeni and Boneti subzones in the Tithonian gray nodular limestones of the Lejowa Valley section, the two subzones being only indicated by scarce chitinoidellid associations and overlying the Parastomiosphaera malmica dinocyst Zone. It is worth mentioning the relative rarity of chitinoidellid species, especially those from the lower Dobeni Subzone, throughout the Carpathian sections compared to our Western Balkan sections and to the legacy of Grigore Pop from the South Carpathians. Partly, the reason might be the presence of radiolarian cherts or shallow carbonate platforms at the lower/upper Tithonian boundary interval, e.g., in the Snežnica, Kurovice, and Lejowa Valley sections, as well as in Turkey (Atasoy et al., 2018) and Oman (Celestino et al., 2017).

In the Velykyi Kamianets section in the Ukraine Carpathians, the Chitinoidella and Praetintinnopsella zones have been detected in the Czorsztyn Limestone Formation (an equivalent of the upper nodular limestones), and the Crassicollaria and Calpionella zones - in the Calpionella-bearing Dursztyn Limestone Formation (Grabowski et al., 2019). The Boneti Subzone is represented by a diverse association, whereas the Dobeni Subzone is only indicated by its index-species as in many other Carpathian sections. Grabowski et al. (2019) presented a correlation between calpionellid zonation and magnetostratigraphy across the Tithonian/Berriasian boundary in several sections of the TransDanubian and Carpathian regions. This direct correlation has revealed that the base of the Boneti Subzone approximates the base of M20r magnetic chron, the top of the Remanei Subzone - the base of M19r magnetic chron, and the base of the Ferasini Subzone correlates well with the M18r chron.

Calpionellid biostratigraphy across the Jurassic/Cretaceous boundary in Morocco and Tunisia is famous for the direct correlation with ammonite successions and zonation that enhances the chrono- stratigraphic value of the calpionellid zones and subzones. Boughdiri et al. (2009), Benzaggagh et al. (2010), and Sallouhi et al. (2011) documented the position of the base of the Boneti Subzone exactly at the Ponti/Microcanthum boundary in terms of ammonites, thus implying that the base of the Boneti Subzone may be used to trace the lower/upper Tithonian boundary.

Although not as comprehensive as in the Central Tethyan Domain, first records of chitinoidellids and calpionellids in the Eastern Tethyan enlarge the geographical distribution and correlation potential of these microfossils, e.g., in Iran (Benzaggagh et al., 2012) and Oman (Celestino et al., 2017).

In the Western Tethyan Domain, recent studies have reported on the presence of the Crassicollaria and Calpionella zones in Mexico and Cuba (see Pszczółkowski, 2013, and references therein). It is also worth mentioning the discovery of chitinoidellids, calpionellids and calcareous dinocysts in the Tithonian/Berriasian boundary strata of the Pacific Region in Argentina (Kietzmann, 2017; Kietzmann et al., 2018).

\section{CONCLUSIONS}

Four calpionellid zones and seven subzones and three calcareous dinocyst zones were documented in the upper part of the Yavorets section.

Chitinoidellids and calpionellids provided new evidence for the early-late Tithonian age of the Gintsi Formation, as well as for the late Tithonian to earliest Berriasian age of the Glozhene Formation, together with calcareous dinocyst biostratigraphy.

The Jurassic/Cretaceous boundary was drawn in the lower part of the Glozhene Formation, based on the last occurrence of Calpionella elliptalpina and the "explosion" of the spherical form of Calpionella alpina (the Crassicollaria colomi)/Calpionella alpina subzonal boundary). It falls into the lower part of the calcareous dinocyst Stomiosphaerina proxima Zone.

A set of three successive microfacies were identified: Saccocoma MF (Gintsi Formation, lower-upper Tithonian); Globochaete alpina MF (Glozhene Formation, upper Tithonian); and calpionellid MF (Glozhene Formation, upper Tithonian-lower Berriasian).

Considering the microfossil constituents and carbonate textures, it can be inferred that the sediments of the Gintsi Formation were accumulated on a structural high of the basin floor, whereas those of the Glozhene Formation were deposited into a deeper-water basin environment. 


\section{Acknowledgements}

This work is a contribution to the bilateral project between the Geological Institute of the Bulgarian Academy of Sciences and the Geological Institute of the Slovak Academy of Sciences (2018-2020) and was financed by the project DNTS Slovakia 01/9 of the Bulgarian Fund "Scientific Research". We thank Dr Lubomir Metodiev and Nikolay Nikolov (Geological Institute, BAS) and Dr Docho Dochev (Sofia University) for their support in the field work. Special thanks are due to Prof. A. Pszczółkowski (Warsaw), Prof. I. Bucur (Cluj-Napoca), and Dr D. A. Kietzmann for their thorough reviews and useful suggestions.

\section{APPENDIX. TAXONOMIC LIST}

Alphabetic list of all chitinoidellid, calpionellid and calcareous dinocyst taxa mentioned in the text and figures is given below. See Furrazola Bermúdez (1965), Borza (1969), Furrazola Bermúdez and Kreisel (1973), Pop (1994a, b, 1996, 1997a, b, 1998a, b), Reháková (1998, 2002), Sallouhi et al. (2011) for chitinoidellids and calpionellids, and Vogler (1941) and Ivanova and Kietzmann (2017, and references therein) for calcareous dinocysts for full taxonomic descriptions with authorship.

\section{Chitinoidellids, semichitinoidellids, and} calpionellids

Almajella Pop, 1998

Almajella cristobalensis (Furrazola Bermúdez, 1965)

Borziella Pop, 1997

Borziella slovenica (Borza, 1969)

Carpathella Pop, 1998

Carpathella rumanica Pop, 1998

Chitinoidella Doben, 1963

Chitinoidella boneti Doben, 1963

Chitinoidella carthagensis Sallouhi, Boughdiri and Cordey, 2011

Chitinoidella elongata Pop, 1997

Chitinoidella hegarati Sallouhi, Boughdiri and

Cordey, 2011

Chitinoidella popi Sallouhi, Boughdiri and Cordey, 2011

\section{Daciella Pop, 1998}

Daciella almajica Pop, 1998

Daciella banatica Pop, 1998

Daciella danubica Pop, 1998

Daciella svinitensis Pop, 1998

Daciella sp.

Dobeniella Pop, 1997

Dobeniella bermudezi (Furrazola Bermúdez, 1965)
Dobeniella colomi (Borza, 1966)

Dobeniella cubensis (Furrazola Bermúdez, 1965)

Dobeniella lubimovae (Furrazola Bermúdez and

Kreisel, 1973)

Dobeniella tithonica (Borza, 1969)

Longicollaria Pop, 1997

Longicollaria dobeni (Borza, 1966)

Longicollaria insueta (Ǩehánek, 1986)

Popiella Reháková, 2002

Popiella oblongata Reháková, 2002

Praetintinnopsella Borza, 1969

Praetintinnopsella andrusovi Borza, 1969

Calpionella Lorenz, 1902

Calpionella alpina Lorenz, 1902

Calpionella elliptalpina Nagy, 1986

Calpionella grandalpina Nagy, 1986

Calpionella minuta Houša, 1990

Calpionella sp. A

Crassicollaria Remane, 1962

Crassicollaria brevis Remane, 1962

Crassicollaria colomi Doben, 1963

Crassicollaria intermedia (Durand Delga, 1957)

Crassicollaria massutiniana (Colom, 1948)

Crassicollaria parvula Remane, 1962

Remaniella Catalano, 1965

Remaniella colomi Pop, 1996

Remaniella duranddelgai Pop, 1996

Remaniella ferasini (Catalano, 1965)

Tintinnopsella Colom, 1948

Tintinnopsella carpathica (Murgeanu and Filipescu, 1933)

Tintinnopsella doliphormis (Colom, 1939)

Tintinnopsella remanei Borza, 1969

\section{Calcareous dinocysts}

Cadosina Wanner, 1940

Cadosina fusca cieszynica Nowak, 1968

Cadosina fusca fusca Wanner, 1940

Colomisphaera Nowak, 1968

Colomisphaera carpathica (Borza, 1964)

Colomisphaera cieszynica Nowak, 1968

Colomisphaera fortis Řehánek, 1982

Colomisphaera lapidosa (Vogler, 1941)

Colomisphaera lucida Borza, 1986

Colomisphaera nagyi Borza, 1969

Colomisphaera pieniniensis (Borza, 1969)

Colomisphaera radiata (Vogler, 1941)

Colomisphaera tenuis (Nagy, 1966)

Committosphaera Řehánek, 1985

Committosphaera sublapidosa (Vogler, 1941)

Crustocadosina Řehánek, 1985

Crustocadosina semiradiata semiradiata (Wanner, 1940)

Crustocadosina semiradiata olzae (Nowak, 1966)

Stomiosphaera Wanner, 1940 
Stomiosphaera acculeata Vogler, 1941

Stomiosphaera misolensis (Vogler, 1941)
Stomiosphaerina Nowak, 1974

Stomiosphaerina proxima Řehánek, 1987

\section{REFERENCES}

Andreini, G., Caracuel, J.E., Parisi, G. 2007. Calpionellid biostratigraphy of the Upper Tithonian-Upper Valanginian interval in Western Sicily (Italy). Swiss Journal of Geosciences 100, 179-198 (https://doi.org/10.1007/s00015007-1227-z).

Angelov, V., Dimitrova, R., Haydoutov, I., Tronkov, D., Sapunov, I., Tchoumatchenko, P., Tzankov, Tz., Yanev, S., Popov, N., Nikolov, T. 1992. Geological map of the Republic of Bulgaria 1:100 000, Berkovitsa map sheet. Committee on Geology, Company for Geophysical surveys and Geological mapping, Sofia.

Atasoy, S.G., Altiner, D., Okay, A.I. 2018. Reconstruction of a Late Jurassic-Early Cretaceous carbonate platform margin with composite biostratigraphy and microfacies analysis (western Sakarya Zone, Turkey): Paleogeographic and tectonic implications. Cretaceous Research 92, 66-93 (https:// doi.org/10.1016/j.cretres.2018.07.009).

Benzaggagh, M., Cecca, F., Rouget, I. 2010. Biostratigraphic distribution of ammonites and calpionellids in the Tithonian of the internal Prerif (Msila area, Morocco). Paläontologische Zeitschrift 84 (2), 301-315 (https://doi.org/10.1007/ s12542-009-0045-1).

Benzaggagh, M., Cecca, F., Schnyder, J., Seyed-Emami, K., Reza Majidifard, M. 2012. Calpionelles et microfaunes pélagiques du Jurassique supérieur - Crétacé inférieur dans les Formations Shal et Kolur (Montagnes du Talesh, chaîne de l'Elbourz, Nord-Ouest Iran). Répartition stratigraphique, espèces nouvelles, révision systématique et comparaisons régionales. Annales de Paléontologie 98, 253-301 (http:// dx.doi.org/10.1016/j.annpal.2012.07.001).

Borza, K. 1969. Die Mikrofazies und Mikrofossilien des Oberjuras und der Unterkreide der Klippen Zone der Westkarpaten. Slovak Academy of Sciences Publishing House, Bratislava, 302 pp.

Boughdiri, M., Sallouhi, H., Haddad, S., Cordey, F., Soussi, M. 2009. Integrated biostratigraphy and regional correlations of Upper Jurassic-lowermost Cretaceous series in northern Tunisia. GFF 131 (1), 71-81 (https://doi. org/10.1080/11035890902847763).

Carević, I., Taherpour-Khalil-Abad, M., Mirković, M., Jovanović, V., Mojtahedin, E., Vušković, D. 2018. Calpionellid biostratigraphy and microfacies of the Upper Tithonian pelagic carbonates in northeastern Serbia (CarpathoBalkanides). Geologica Carpathica 69 (3), 301-311 (https://doi.org/10.1515/geoca-2018-0018).

Celestino, R., Wohlwend, S., Reháková, D., Weissert, H. 2017. Carbon isotope stratigraphy, biostratigraphy and sedimentology of the Upper Jurassic - Lower Cretaceous Rayda Formation, Central Oman Mountains. Newsletters on Stratigraphy 50 (1), 91-109 (https://doi.org/10.1127/ nos/2016/0309).

Clari, P.A., Martire, L. 1996. Interplay of cementation, mechanical compaction, and chemical compaction in nodular limestones of Rosso Ammonitico Veronese (Middle-Upper Jurassic, northeastern Italy). Journal of Sedimentary Petrology 66 (3), 447-458 (https://doi.org/10.1306/D426836F2B26-11D7-8648000102C1865D).

Dabovski, H., Zagorchev, I. 2009. Introduction: Mesozoic evolution and Alpine structure. In: Zagorchev, I., Dabovski, H., Nikolov, T. (Eds), Geology of Bulgaria. Vol. II. Mesozoic geology. "Prof. Marin Drinov” Academic Press, Sofia, 15-37.

Dunham, R.J. 1962. Classification of carbonate rocks according to depositional texture. In: Ham, W.E. (Ed.), Classification of carbonate rocks. American Association of Petroleum Geologists, Memoir 1, 108-171.

Elbra, T., Bubík, M., Reháková, D., Schnabl, P., Čížková, K., Pruner, P., Kdýr, Š., Svobodová, A., Švábenická, L. 2018. Magneto- and biostratigraphy across the Jurassic-Cretaceous boundary in the Kurovice section, Western Carpathians, Czech Republic, Cretaceous Research 89, 211-223 (https://doi.org/10.1016/j.cretres.2018.03.016).

Flügel, E. 2004. Microfacies of Carbonate Rocks. Springer, Berlin, 976 pp.

Furrazola Bermúdez, G. 1965. Tres nuevas especies de tintinidos del Jurásico superior de Cuba. Instituto Cubano de Recursos Minerales, Publicación Especial 2, 3-39.

Furrazola Bermúdez, G., Kreisel, K. 1973. Los tintinidos fósiles de Cuba. Revista Tecnológica 1 (73), 27-45.

Grabowski, J., Haas, J., Márton, E., Pszczółkowski, A. 2010. Magneto- and biostratigraphy of the Jurassic/Cretaceous boundary in the Lókút section (Transdanubian Range, Hungary). Studia Geophysica et Geodaetica 54, 1-26 (https:// doi.org/10.1007/s11200-010-0001-2).

Grabowski, J., Lakova, I., Petrova, S., Stoykova, K., Ivanova, D., Wójcik-Tabol, P., Sobień, K., Schnabl, P. 2016. Paleomagnetism and integrated stratigraphy of the Upper Berriasian hemipelagic succession in the Barlya Section Western Balkan, Bulgaria: Implications for lithogenic input and paleoredox variations. Palaeogeography, Palaeoclimatology, Palaeoecology 461, 156-177 (http://dx.doi. org/10.1016/j.palaeo.2016.08.018).

Grabowski, J., Bakhmutov, V., Kdýr, S., Krobicki, M., Pruner, P., Reháková, D., Schnabl, P., Stoykova, K., Wierzbowski, H. 2019. Integrated stratigraphy and palaeoenvironmental interpretation of the Upper Kimmeridgian to Lower Berriasian pelagic sequences of the Velykyi Kamianets section (Pieniny Klippen Belt, Ukraine). Palaeogeography, Palaeoclimatology, Palaeoecology 532 (https://doi. org/10.1016/j.palaeo.2019.05.038).

Houša, V. 1987. Ecological aspects of the evolution of calpionellids (Calpionellidae; Protozoa inc. sed.). In: Pallini, G., Cecca, F., Cresta, S., Santantonio, M. (Eds), Atti del second Convegno Internazionale "Fossili, Evoluzione, Ambiente", Pergola 1987. Comitato Centenario Raffaele Piccinini, Pergola, 357-363. 
Ivanova, D., Kietzmann, D. 2017. Calcareous dinoflagellate cysts from the Tithonian-Valanginian Vaca Muerta Formation in the southern Mendoza area of the Neuquén Basin, Argentina. Journal of South American Earth Sciences 77, 150-169 (http://dx.doi.org/10.1016/j.jsames.2017.05.004).

Jach, R. 2007. Bositra limestones - a step towards radiolarites: case study from the Tatra Mountains. Annales Societatis Geologorum Poloniae 77 (2), 161-170.

Jach, R., Reháková, D., Uchman, A. 2012. Biostratigraphy and palaeoenvironment of the Kimmeridgian-Lower Tithonian pelagic deposits of the Krížna Nappe, Lejowa Valley, Tatra Mts. (southern Poland). Geological Quarterly 56 (4), 773788 (http://dx.doi.org/10.7306/gq.1054).

Jenkyns, H.C. 1974. Origin of red nodular limestones (Ammonitico Rosso, Knollenkalke) in the Mediterranean Jurassic: a diagenetic model. Special Publications of the International Association of Sedimentologists 1, 249-271.

Kietzmann, D. 2017. Chitinoidellids from the Early TithonianEarly Valanginian Vaca Muerta Formation in the Northern Neuquén Basin, Argentina. Journal of South American Earth Sciences 76, 152-164 (http://dx.doi.org/10.1016/j. jsames.2017.03.005).

Kietzmann, D.A., Iglesia Llanos, M.P., Ivanova, D.K., Kohan Martínez, M., Sturlesi, M.A. 2018. Toward a multidisciplinary chronostratigraphic calibration of the Jurassic-Cretaceous transition in the Neuquén Basin. Revista de la Asociación Geológica Argentina 75 (2), 175-187.

Košt’ák, M., Vaňková, L., Mazuch, M., Bubík, M., Reháková, D. 2018. Cephalopods, small vertebrate fauna and stable isotope $\left(\delta^{13} \mathrm{C}, \delta^{18} \mathrm{O}\right)$ record from the Jurassic-Cretaceous transition (uppermost Crassicollaria through Calpionella Zones) of the Outer Western Carpathians, Kurovice quarry (Czechia). Cretaceous Research 92, 43-65 (https://doi. org/10.1016/j.cretres.2018.05.011).

Kowal-Kasprzyk, J. 2014. North-Tethyan Tithonian chitinoidellids from exotic limestone pebbles in the Silesian Nappe (Polish Outer Carpathians). Geologica Carpathica 65 (1), 25-34 (https://doi.org/10.2478/geoca-2014-0002).

Kowal-Kasprzyk, J. 2018. Calpionellid zones of the TithonianBerriasian exotic limestone clasts from the Outer Carpathians, Poland. Cretaceous Research 81, 36-50 (https://doi. org/10.1016/j.cretres.2017.09.005).

Kowal-Kasprzyk, J., Reháková, D. 2019. A morphometric analysis of loricae of the genus Calpionella and its significance for the Jurassic/Cretaceous boundary interpretation. Newsletters on Stratigraphy 52 (1), 33-54 (https://doi. org/10.1127/nos/2018/0461).

Lakova, I. 1994. Numerical criteria of precise delimitation of the calpionellid Crassicollaria and Calpionella Zones in relation to the Jurassic/Cretaceous system boundary. Geologica Balcanica 24 (6), 23-30.

Lakova, I., Petrova, S. 2013. Towards a standard Tithonian to Valanginian calpionellid zonation of the Tethyan Realm. Acta Geologica Polonica 63 (2), 201-222 (https://doi. org/10.2478/agp-2013-0008).

Lakova, I., Stoykova, K., Ivanova, D. 1999. Calpionellid, nannofossil and calcareous dinocyst bioevents and integrated biochronology of the Tithonian to Valanginian in the Western Balkanides, Bulgaria. Geologica Carpathica 50 (2), 151-168.

Lakova, I., Tchoumatchenco, P., Ivanova, D., Koleva-Rekalova, E. 2007. Callovian to Lower Cretaceous carbonates in the West Balkan Mountains (Komshtitsa and Barlya sections): integrated biostratigraphy and microfacies. Geologica Balcanica 36 (3-4), 81-89.

Mandov, G. 1972. Sur l’âge de dépots du Crétacé inférieur dans le synclinal de Javorec (Balkan Occidental). Annuaire de
l'Université de Sofia, Faculté de Géologie et Géographie 64 (1), 21-27 (in Bulgarian, with French abstract).

Metodiev, L., Sapunov, I. 2008. Diachronous Upper Jurassic Gintsi Formation in the Gubesh and Izdremets Synclines (Western Balkan Mts., Bulgaria). In: Jubilee Scientific Session "60 Years Geology in Sofia University", Abstracts, 57-61.

Michalík, J., Reháková, D. 2011. Possible markers of the Jurassic/Cretaceous boundary in the Mediterranean Tethys: A review and state of art. Geoscience Frontiers 2 (4), 475490 (https://doi.org/10.1016/j.gsf.2011.09.002).

Michalík, J., Reháková, D., Grabowski, J., Svobodová, A., Schlögl, J., Sobień, K., Schnabl, P. 2016. Stratigraphy, plankton communities, and magnetic proxies at the Jurassic/Cretaceous boundary in the Pieniny Klippen Belt (Western Carpathians, Slovakia). Geologica Carpathica 67 (4), 303-328 (https://doi.org/10.1515/geoca-2016-0020).

Michalík, J., Reháková, D., Lintnerová, O., Goričan, Š., Švábenická, L., Fekete, K. 2019. $2^{\text {nd }}$ stop - Snežnica section. In: Fekete, K., Michalík, J., Reháková, D. (Eds), XIV ${ }^{\text {th }}$ Jurassica Conference and Workshop of the ICS Berriasian Group, Field Trip Guide and Abstracts Book, June 10-14, 2019 Bratislava, Slovakia, Earth Science Institute, Slovak Academy of Sciences and Faculty of Natural Sciences, Comenius University, 42-60.

Nagy, I. 1986. Investigation of calpionellides from the Mecsek Mountains (S. Hungary). Acta Geologica Hungarica 29 (1-2), 45-64.

Nikolov, T., Sapunov, I. 1970. On the regional stratigraphy of the Upper Jurassic and part of the Lower Cretaceous in Balkanides. Comptes rendus de l'Académie bulgare des Sciences 23 (11), 1397-1400 (in Russian).

Petrova, S. 2010. Calpionellid data on Berriasian age of the Sarbenitsa Wedge, Cherni Osam Formation (Western Balkan Mountains, Bulgaria). Comptes rendus de l'Académie bulgare des Sciences 63 (5), 733-740.

Petrova, S., Rabrenović, D., Lakova, I., Koleva-Rekalova, E., Ivanova, D., Metodiev, L., Malešević, N. 2012. Biostratigraphy and microfacies of the pelagic carbonates across the Jurassic/Cretaceous boundary in eastern Serbia (Stara Planina-Poreč Zone). Geologica Balcanica 41 (13), 53-76.

Pop, G. 1974. Les zones de calpionellidés tithoniques-valanginiennes du sillon de Reşiţa (Carpathes Méridionales). Revue roumaine de géologie géophysique et géographie, série Géologie 18, 109-125.

Pop, G. 1994a. Systematic revision and biochonology of some Berriasian-Valanginian calpionellids (genus Remaniella). Geologica Carpathica 45 (6), 323-331.

Pop, G. 1994b. Calpionellid evolutive events and their use in biostratigraphy. Romanian Journal of Stratigraphy 76, 7-24.

Pop, G. 1996. Trois nouvelles espèces du genre Remaniella (Calpionellidae Bonet, 1956). Comptes rendus de l'Académie des Sciences de Paris, Série IIa 322, 317-323.

Pop, G. 1997a. Révision systématique des chitinoïdelles Tithoniennes des Carpathes méridionales (Roumanie). Comptes Rendus de l'Académie des Sciences Paris, Série IIa 324, 931-938 (https://doi.org/10.1016/S1251-8050(97)82507-4).

Pop, G. 1997b. Tithonian to Hauterivian praecalpionellids and calpionellids: bioevents and biozones. Mineralia Slovaca 29 (4-5), 304-305.

Pop, G. 1998a. Nouvelles chitinoïdelles tithoniennes des Carpathes méridionales (Roumanie). Comptes rendus de l'Académie des Sciences, Paris, Série de la tèrre et des planètes 326, 817-822 (https://doi.org/10.1016/S12518050(98)80248-6). 
Pop, G. 1998b. Stratigraphic distribution and biozonation of Tithonian praecalpionellids and calpionellids from the South Carpathians. Romanian Journal of Stratigraphy 77, 3-25.

Pruner, P., Houša, V., Olóriz, F., Košt’ák, M., Krs, M., Man, O., Schnabl, P., Venhodová, D., Tavera, J.M., Mazuch, M. 2010. High-resolution magnetostratigraphy and biostratigraphic zonation of the Jurassic/Cretaceous boundary strata in the Puerto Escaño section (southern Spain). Cretaceous Research 32, 192-206 (https://doi.org/10.1016/j. cretres.2009.10.004).

Pszczółkowski, A. 2013. Comment on "Calpionellid distribution and microfacies across the Jurassic/Cretaceous boundary in western Cuba (Sierra de los Órganos)” by LópezMartínez et al. (2013). Geologica Carpathica 64 (6), 497498 (https://doi.org/10.2478/geoca-2013-0034).

Reháková, D. 1995. Nové poznatky o distribúcii kalpionelíd vo vrchnojurských a spodnokriedových súvrstviach Západných Karpát. Mineralia Slovaca 27, 308-318.

Reháková, D. 1998. Calpionellid genus Remaniella Catalano 1956 in Lower Cretaceous pelagic deposits of western Carpathians. Mineralia Slovaca 30 (6), 443-452.

Reháková, D. 2002. Chitinoidella Trejo, 1975 in the middle Tithonian carbonate pelagic sequences of the West Carpathian Tethyan area. Geologica Carpathica 53 (6), 369-379.

Reháková, D., Matiyja, B., Wierzbowski, A., Schlögl, J., Krobicki, M., Barski, M. 2011. Stratigraphy and microfacies of the Jurassic and lowermost Cretaceous in the Veliky Kamenets section (Pieniny Klippen Belt, Carpathians, Western Ukraine). Volumina Jurassica 9, 61-104 (https:// doi.org/10.5604/17313708 .1114179).

Reháková, D., Michalík J. 1997. Evolution and distribution of calpionellids - the most characteristic constituents of Lower Cretaceous Tethyan microplankton. Cretaceous Research 18, 495-504 (https://doi.org/10.1006/cres.1997.0067).

Remane, J. 1963. Les calpionelles dans les couches de passage Jurassique-Crétacé de la fosse vocontienne. Travaux de Laboratoire de Géologie, Grenoble 39, 25-82.

Remane, J., Bakalova-Ivanova, D., Borza, K., Knauer, J., Nagy, I., Pop, G. and Tardi-Filacz, E. 1986. Agreement on the subdivision of the standard calpionellid zones defined at the II planktonic conference, Roma 1970. Acta Geologica Hungarica 29, 5-14.

Sallouhi, H., Boughdiri, M., Cordey, F. 2011. Tithonian Chitinoidellids of the South-Tethyan Margin of the Maghreb: New data from Tunisia. Comptes Rendus Palevol 10, 641653 (https://doi.org/10.1016/j.crpv.2011.08.003).

Sapunov, I. 1976. Ammonite stratigraphy of the Upper Jurassic in Bulgaria. I. Rock and ammonite successions. Geologica Balcanica 6 (3), 17-40.

Sapunov, I. 1977a. Ammonite stratigraphy of the Upper Jurassic in Bulgaria. III. Kimmeridgian substages, zones and subzones. Geologica Balcanica 7 (1), 63-80.

Sapunov, I. 1977b. Ammonite stratigraphy of the Upper Jurassic in Bulgaria. IV. Tithonian substages, zones and subzones. Geologica Balcanica 7 (2), 43-64.

Skupien, P., Doupovcová, P. 2019. Dinoflagellates and calpionellids of the Jurassic-Cretaceous boundary, Outer Western Carpathians (Czech Republic). Cretaceous Research 99, 209-229 (https://doi.org/10.1016/j.cretres.2019.02.017).

Svobodová, A., Švábenická, L., Reháková, D., Svobodová, M., Skupien, P., Elbra, T., Schnabl, P. 2019. The Jurassic/ Cretaceous boundary and high resolution biostratigraphy of the pelagic sequences of the Kurovice section (Outer Western Carpathians, the northern Tethyan margin). Geologica Carpathica 70 (2), 153-182 (https://doi.org/10.2478/geoca-2019-0009).

Vogler, J. 1941. Ober Jura und Kreide von Misol (Niederländisch-Ostindien). Palaeontographica 4, 246-293.

Wieczorek, J. 1988. Maiolica - a unique facies of the Western Tethys. Annales Societatis Geologorum Poloniae 58 (3-4), 255-276.

Wimbledon, W.A.P. 2017. Development with fixing the Tithonian/Berriasian (J/K) boundary. Volumina Jurassica 15, 181-186 (https://doi.org/10.5604/01.3001.0010.7467).

Wimbledon, W.A.P., Reháková, D., Pszczółkowski, A., Casellato, C.E., Halásová, E., Frau, C., Bulot, L.G., Grabowski, J., Sobień, K., Pruner, P., Schnabl, P., Čížková, K. 2013. An account of the bio- and magnetostratigraphy of the Upper Tithonian-Lower Berriasian interval at Le Chouet, Drôme (SE France). Geologica Carpathica 64, 437-460 (https://doi.org/10.2478/geoca-2013-0030). 